\title{
Yapay Kıyıların Jeomorfolojik Tanımlaması: Diliskelesi Kıyıları Örneği (Kocaeli, Türkiye)
}

\section{Geomorphological Identification of Artificial Coasts: The Case of Diliskelesi (Kocaeli, Turkey)}

\author{
Hüseyin TUROĞLU ${ }^{1}$ (D) \\ 'İstanbul Üniversitesi, Edebiyat Fakültesi, Coğrafya Bölümü, İstanbul, Türkiye
}

ORCID: H.T. 0000-0003-0173-6995

\section{öz}

Yapay kıyıların jeomorfolojik tanımlamaları ile hukuki problemlerin çözümlerine ait teknik yaklaşımlar arasında bazı problemlerin olduğu görülmektedir. Bu çalışmada; yapay kıyıların jeomorfolojik tanımlamasının yapılması ve mülkiyet problemleri temelli hukuki sorunların çözümüne yönelik bakış açısı verilmesi amaçlanmıştır. Öncelikle, konu ile ilgili teorik altyapı tanımlaması yapılmıştır. Örnekleme sahası olarak, tipik bir yapay kıyı jeomorfoloji özelliğine sahip olan Diliskelesi kıyıları tercih edilmiştir. Bu çerçevede; ArcMap 10.2 yazılımı kullanılarak, 1962 ve 1976 tarihli hava fotoları, güncel Google Earth görüntüleri, batimetri ve sondaj verileri, 1/25000 ölçekli 1972 tarihli topografya haritası, eski tarihli fotoğraflardan faydalanılmıştır. Jeomorfolojik olarak kıyı; güncel morfodinamik etken ve süreçlerin şekillendirici faaliyetleri altında olan, güncel bir yeryüzü şeklidir. Kıyı, kıyının bölümleri ve onların sınırları denizselliğin indikatör delillerine dayandırılan bir tanımlama ile yapılır. Mülkiyet problemlerine ait davaların çözümünde ise yapay kıyıya ait dolgu alanının yatay ve düşeydeki sınırları ve ayrıca eski doğal kıyının sınırlarının belirlenmesine ihtiyaç vardır.

Anahtar kelimeler: Doğal kıyı, yapay kıyı, jeomorfoloji

\section{ABSTRACT}

Problems exist regarding not just the geomorphological definition of what constitutes an artificial coast but also the technical approach used in resolving legal issues with such coasts. The aim of this study was to construct a geomorphological description of what an artificial coast is and to express the geomorphological point of view for solving legal problems arising from the ownership of areas reclaimed by filling in part of the sea. Firstly, natural coasts and their constituent parts and boundaries are described from a geomorphological perspective. The coast of Diliskelesi and its vicinity was selected as the sample site. The research utilised ArcMap 10.2 software, aerial photos from 1962 and 1976, current Google Earth images, bathymetry and drilling data, a 1972 1:25000 scale topographical map, and old photographs of the location studied. Geomorphologically, a coast is a landform with a surface of earth under the influence of current geomorphological processes. The definition of a coast, parts of a coast and its boundaries are based on indicative evidence of marine effects. To find a solution to litigation issues on artificial coast ownership, the horizontal and vertical boundaries of the area of the artificial coast need to be determined, as well as the borders of the old natural coast.

Keywords: Natural coast, artificial coast, geomorphology 


\section{EXTENDED ABSTRACT}

A coast is a geomorphological unit with unique characteristics representing a landform in-between a body of water (marine, lake, river) and a land environment (Turoğlu, 2017a). Due to its widespread use in this study, the water body is referred to here as the "Sea". The "Marine Coastal Borderline" is the sea-side border of the coast and the "Terrestrial Coastal Borderline" represents the border of the coast on the land side. The area between these two borders is a landform, a geomorphic unit, termed a "Coast". The line formed by the points where the sea water touches the land is defined as the "Shoreline" (Erinç, 1971; Turoğlu, 2017a). The Nearshore, Foreshore, and Backshore are all parts of a natural coast (Erol, 1991; Turoğlu, 2017a). The parts of a natural coast are determined based on geomorphological, hydrographic, biogeographical and sedimentological evidence (Edwards, 2001; Bird, 2008; DavidsonArnott, 2010; Erginal \& Öztürk, 2010; Karunarathna, 2012; Avc1, 2017). Artificial coasts arise from filling of the sea either legally or illegally for various reasons (Anthony, 1994; Kelletat, 1995; Hudson, 1980; Szabó, 2010; Kobayashia, 2015; Li et al., 2017; Turoğlu, 2019). Problems are experienced in construing the geomorphological definition of an artificial coast along with its planning and usage, property issues, etc. In order to solve these problems, Turkish Coastal Law was taken as the basis of this study and expert opinions were obtained. Moreover, it should be noted that different assessments have been made of similar problems.

This study aims to provide a geomorphological description of artificial coasts in which the natural shore, natural coastal parts and boundary features are discussed as well as their meaning and significance in the legal framework of artificial coastal geomorphology. The geomorphology of the Diliskelesi (Koceli, Turkey) coast was selected as the case study area because it has examples of typical artificial coastal features. The subject was investigated working with 1:18000 scale aerial photographs from 1962 and 1976, current Google Earth images, a 1:25000 scale topography map dated from 1972, old photos, bathymetry data, and ArcMap 10.2 software. The evaluation results were tested and verified with field observations.

"Diliskelesi coast" as a geomorphologic unit is described as having artificial coastal geomorphology. From the 1962 aerial photographs, it is understood that the geomorphology of the study area was a natural coast consisting of "Narrow-High Coast" and "Large-Low Coast" types. In the early 1960s, during the construction of a railway line and tunnel, the sea was filled with excavated material, representing the first stage in Diliskelesi becoming an artificial coast. In the following years, filling the harbour/port along with dock construction continued and the current artificial coast was formed. The area and dimensions of the artificial coast were determined by evaluating drilling data and old photographs. The thickness of the artificial filler, depth of marine sediments, bedrock depths and drilling locations were used as the determinative data.

As a result, the coast was transformed into the current geomorphological unit. Indicator evidence defines the coast as being shaped and developed under the influence of current morphodynamic factors and processes. The coast now being artificial may cause differences in the activity of current morphodynamic factors and processes but does not change the reality of the "current coast" from the geomorphological perspective. Morphodynamic factors and processes continue to affect erosion, transportation and accumulation based on the characteristics of man-made artificial coastal geomorphology, maintaining the shape of the new artificial coast. The previous natural coast is now an old (paleo) coast, and has geomorphologically lost its coastal nature. The usage of artificial coasts and property problems are different aspects of the issue and should be evaluated within the framework of legal regulations. 


\section{GÍRIŞ}

Deniz, göl ve akarsu kıyıları güncel morfodinamik etken ve süreçler ile şekillenen, kendine has tanımlayıcı karakteristik özellikleri olan jeomorfolojik bir ünitedir. $\mathrm{Bu}$ jeomorfolojik birim; dalga ve akıntıların, rüzgârın, yer yer akarsuyun ve hatta kimi yerlerde buzulların, birer jeomorfolojik etken olarak rol aldığı, bu etkenlerin aşındırma, taşıma ve biriktirme faaliyetleri ile aktif olmasıyla gerçekleşen bir gelişimin doğal sonucu olarak şekillenir (Turoğlu, 2017a). Bir başka ifadeyle; yeryüzü şekli olan kıyının oluşumu, gelişimi ve değişim özellikleri morfodinamik etken ve süreçler ile ilgili olup, kıyı oluşumunun temel belirleyicisidir. Kıyının bir başka önemli özelliği ise güncel olmasıdır. Kıyı; güncel morfodinamik etken ve süreçlerin aşındırma, taşıma ve biriktirme faaliyetleri ile morfolojik karakterini kazanır. Zaman içinde, şekillendirici faktörlerde meydana gelecek farklılaşma, kıyının bölümleri ve sınır özelliklerinde, kıyı jeomorfolojisinde değişime neden olabilir. Hatta doğal sebeplerle, kıyı; eski kıyı niteliği kazanabilir. Kıyı üzerinde gerçekleşen doğal ya da yapay değişiklikler, onu oluşturan güncel jeomorfolojik etken ve süreçlerin faaliyetlerine ait tür ve şiddet özelliklerinin de değişmesine neden olur. Yeni bir "etken, süreç, yapı etkileşim sistemi" çalışmaya başlar. Bu durumda, önceki kıyı ve onu oluşturan morfodinamik sistem değişmiştir. Yüzeyde ya da örtülü olarak, önceki kıyıya ait denizselliğin delilleri olsa dahi, güncel olmadığı için bunlar artık paleo olarak kabul edilmelidir.

Yeni kıyının belirlenmesi, kıyıı ve kıyı elemanlarını tanımlayan jeomorfolojik, hidrografik, biyocoğrafik, sedimantolojik güncel delillere dayandırılarak yapılır. Kıyının insan tarafından değiştirilmiş olması hali de bu yaklaşımı ve kıyı tanımlama kriterlerini sonuç itibarıyla değiştirmez. Zira kıyının bilimsel belirlenmesi, onun nasıl oluştuğundan ziyade, onu tanımlayan bilimsel indikatör delilere dayandırılır. Kıyı kullanımı, mülkiyet konuları ve ilgili yasal düzenlemeler ise kıyı tanımlamasının, kıyı elemanlarının, bölümlerinin bilimsel belirlenmesinin dışındaki yasal presüdürü olan hususlardır.

Sulh Hukuk Mahkemelerinde dolgu ile denizden kazanılmış alanların mülkiyet problemlerine ait "Kıyı" ve "Kıуı Kenar Çizgisi" tespitlerini sorgulayan çok sayıda dava devam etmektedir. Bu davalarda, bilirkişi heyetinden dolgu alanının, doğal kıyının ve Kıyı Kenar Çizgisinin belirlenmesi istenmektedir. Hazırlanan bilirkişi heyet raporları, davalı ve davacılar tarafından çoğu kez tartış1lır olmakta, davalar uzayıp gitmektedir. Konunun bu hale dönüşmesi; Kıyı jeomorfolojisi, Kıyıyı tanımlayan indikatör deliller, kıyının şekillenmesinde rol alan güncel morfodinamik etken ve süreçler hakkında genel kabul ediş eksikliği ve oluşturulan bilirkişi heyetinin bu konulardaki yeterlilikleri ile ilgili olmalıdır. $\mathrm{Bu}$ kapsamda "Yapay Kıyılar" mevzu ise söz konusu problemler içinde özel bir öneme sahiptir ve bu çalışmanın ana temasını oluşturmaktadır.

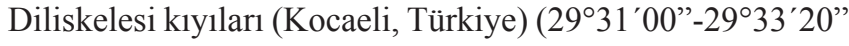
D ve $40^{\circ} 45^{\prime} 46^{\prime \prime}-40^{\circ} 46^{\prime} 37^{\prime \prime} \mathrm{K}$ ), bölge ve ülke için stratejik öneme sahip kıyı alanlarından biridir (Şekil 1). 1970 li yılların başlarından itibaren başlayan insan müdahalelerine sahne olmuş ve kıyının doldurulmasıyla doğal kıyı niteliğini tamamen kaybetmiştir. Fonksiyonel olarak; deniz taşımacılığı, liman işletmeciliği, kimyasal ürün depolama ve sevkiyat faaliyetleri amaçlı projelendirilmiştir. $\mathrm{Bu}$ faaliyetlerin gerçekleşmesinde deniz ve bağlantılı kara taşımacılığının gereği büyük tonajlı gemilerin bu kıyılardaki limanlara yanaşması, ayrıca ürünlerin sevkiyatı için yine büyük tonajlı kara araçlarının yüklemeboşaltma ve manevra yapmalarına firsat verecek iskele platformları oluşturulmuştur.

$\mathrm{Bu}$ çalışmada; hem bilimsel olarak ve hem de hukuki mülkiyet problemlerinin çözümünde dikkate alınması amacıyla, yapay kıyı ve onun bölümleri, yapay kıyıların sınır özelliklerinin jeomorfolojik tanımlamasının yapılması hedeflenmiştir. İnsan müdahalesi ile doldurularak oluşturulan yapay kıyılarının jeomorfolojik tanımlamasına ait örnekleme için Diliskelesi yapay kıyıları ele alınmıştır. Hem stratejik ve hem de mülkiyet kıymeti böylesine büyük öneme sahip, doğal kıyının doldurulmasıyla oluşturulan bu yapay kıyı şu sorular ile tartışılmıştır. Diliskelesi yapay kıyıları için kıyı neresidir? Kıyı Çizgisi, Kıyı Kenar Çizgisi nereden geçer? Bu yapay kıyılarda kıyı ve kıyı elemanları nasıl tanımlanacak, belirlenecek?

Diliskelesi örneklemesinde; 1/18000 ölçekli 1962 ve 1976 y1llarına ait hava fotoları, altlık olarak 11 Şubat 2019 tarihli Google Earth görüntüsü, batimetrik örnekleme olarak Narca Dere ağızı ve yakın çevresi liman içi deniz derinlik verileri, Narca Dere ağızı ve yakın çevresinde yapılmış olan dolgu belirleme sondajları, 1972 tarihli 1/25000 ölçekli topografya haritası, eski tarihli fotolar bu araştırmada kullanılan verilerdir. Haritalar, hava fotoları ve batimetrik verilere ait çalışmalar ArcMap 10.2 yazılımı imkânları ile gerçekleştirilmiştir. Bu kapsamda; 1962 ve 1976 yıllarına ait hava fotolarının, 1972 tarihli 1/25000 ölçekli topografya haritasının Georeferanslamaları yapılmıştır. Güncel kıyı özellikleri ise ArcMap 10.2 yazılımı menüsünde "Add Basemap" sekmesi aracılığ1 ile "Imagery" görüntüsünden elde edilmiştir. İlgili tarihlere ait kıyı çizgileri sayısallaştırılmıştır. Ayrıca deniz 


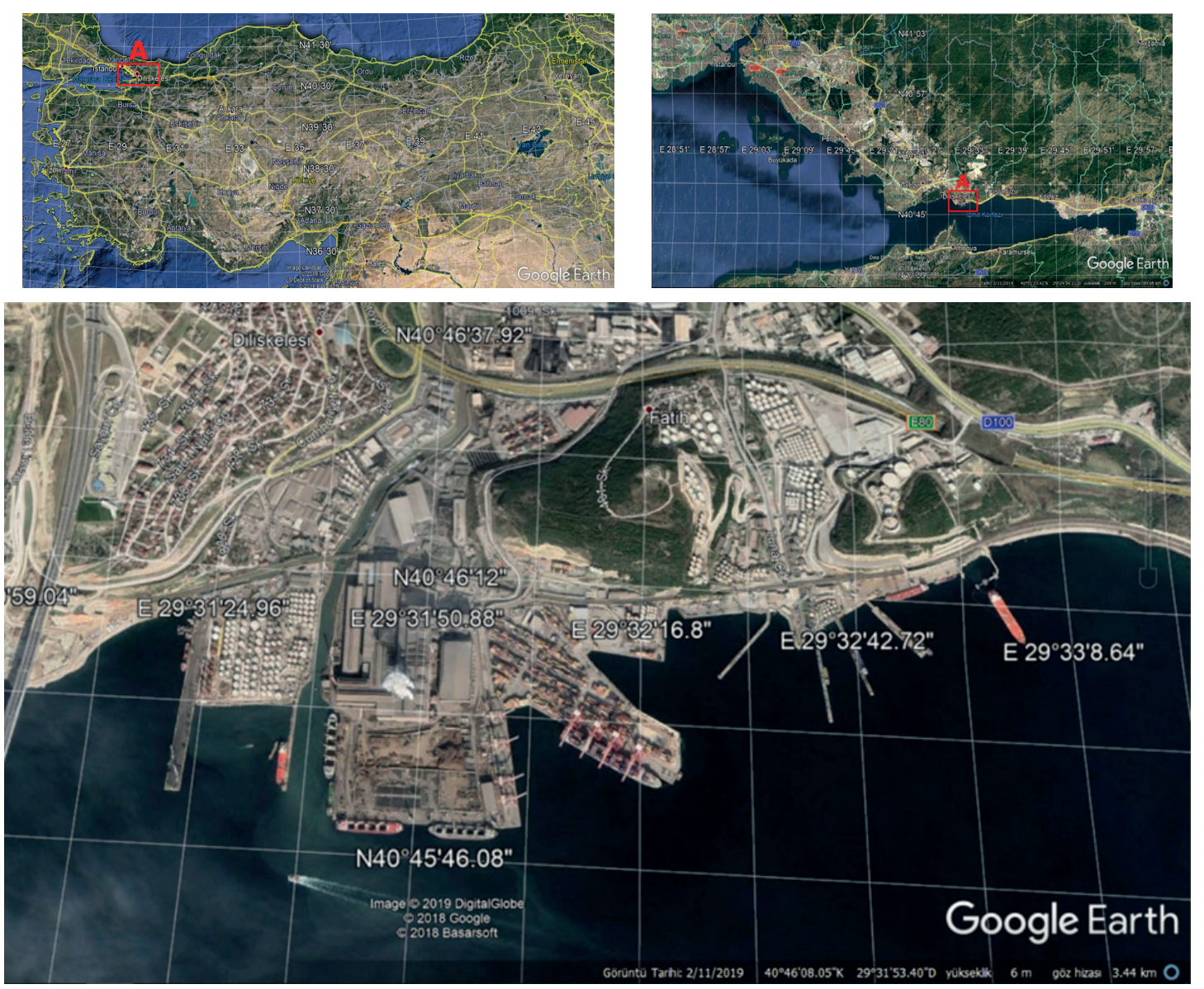

Şekil 1: Çalışma sahasının lokasyonu ve güncel kıyı.

Figure 1: Location of the study area and the current coast.

suyu derinlik ölçümlerine ve sondaj lokasyonlarına ait veri tabanı oluşturulmuştur. $\mathrm{Bu}$ verilerin birbirleri ile ilişkilendirilmesi ve görselleştirilmeleri de yine ArcMap 10.2 yazılımı imkânları ile yapılmıştır.

\section{DOĞAL KIYILAR}

Bir yeryüzü şekli olarak kıyı; jeomorfolojik etken ve süreçlerin kontrolünde oluşan, doğal (deniz, göl, akarsu) ya da yapay (baraj, gölet vb.) su kütleleri ile kara koşullarının hâkim olduğu saha arasındaki geçiş bölgesini, ara zonu temsil eder (Turoğlu, 2009; Turoğlu, 2017a). Bu geçiş zonu, su kütlesi tarafından "Denizel Kıyı Kenar Çizgisi (DKKÇ)", kara tarafından ise "Karasal Kıyı Kenar Çizgisi (KKKÇ)" ile sınırlandırılmıştır (Erol, 1989; Turoğlu, 2017a). Ayrıca maksimum çekik ve maksimum yüksek su seviyelerine ait kıyı çizgileri kıyının bölümlerini belirleyen diğer sınırlardır (Şekil 2, 3). Göl, akarsu, baraj, vb. su kütleleri kıyı jeomorfolojisine sahip olmasına rağmen, kıyı tanımlamaları, yaygınlığı nedeni ile "Deniz kıyıları" üzerinden yapılmaktadır.
Kıyılar; kökenlerine göre çeşitli şekillerde sınıflandırılabilir (Johnson, 1919; Shepard, 1963; Erinç, 1971; Erinç, 1986; Fairbridge, 2004; Bird, 2008; Davidson-Arnott, 2010). Bu sinıflandırmalar genel olarak yapısal özellikler ile doğal jeomorfolojik etken ve süreçlere dayandırılır. Tektonik ve bazen volkanik faaliyetlerin şekillendirdiği ana yapı (Inman ve Nordstrom, 1971) üzerinde; akarsular, dalga ve akıntılar, rüzgârlar ve buzulların aşındırma, taşıma ve biriktirme yaparak, şekillendirdiği, kökensel/jenetik sınıflandırmaya temel teşkil eden farklı kıyı tiplerini oluştururlar.

Bu çalışmada kıyı, kökensel/jenetik özelliğine bakılmaksızın, morfolojik özellikleri itibarılya; "Geniş-Alçak kıyılar" ve "DarYüksek kıyılar" olarak sınıflandırılmıştır (Turoğlu, 2017a). Bu sinıflandırmanın tercih edilmesinde, yasal prosedüre uygunluk göstermesi de ayrıca etkili olmuştur. "Geniş-Alçak klyl”" tipi; kıyı bölümlerinin tümünü (yakın kıyı, önkıyı ve artkıyı) bünyesinde barındıran ve onların belirlenmesinde rol alan tanımlayıcı denizsellik indikatörü delillerin (Turoğlu, 2017a) gözlendiği kıyı tipidir (Şekil 2). "Dar-Yüksek klyl" tipi ise 


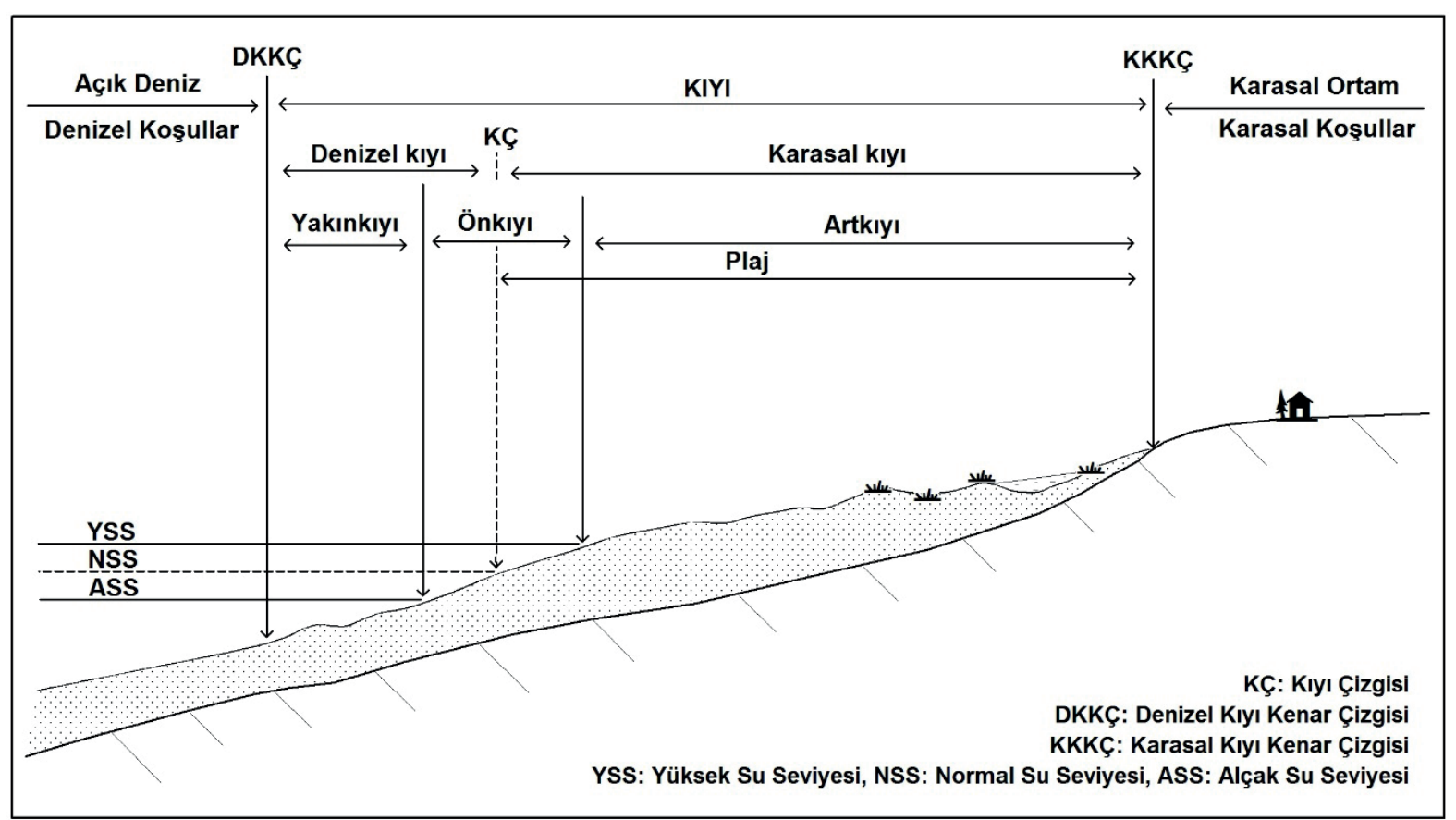

Şekil 2: "Geniş-Alçak kıyı" tipi ve onun kıyı elemanları (Turoğlu, 2017a).

Figure 2: "Large-Low coast" type and its coastal elements (Turoglu, 2017a).
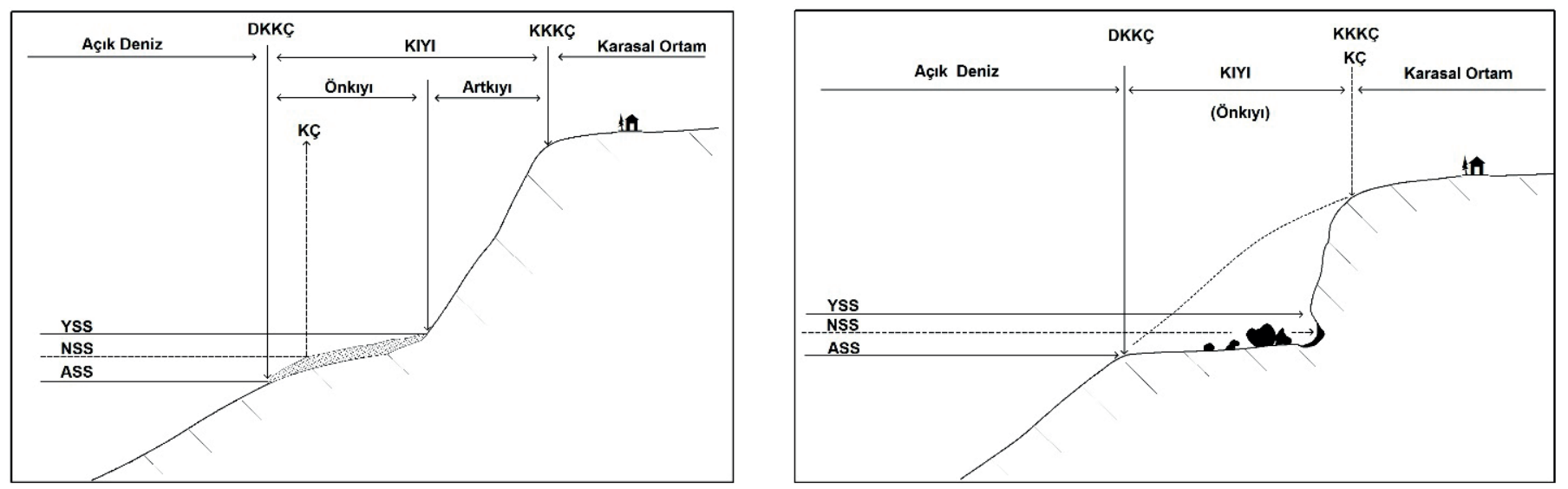

Şekil 3: "Dar-Yüksek kıyı” ve onun kıyı elemanları (DKKÇ: Denizel Kıyı Kenar Çizgisi, KKKÇ: Karasal Kıyı Kenar Çizgisi, KÇ: Kıyı Çizgisi, YSS: Yüksek Su Seviyesi, NSS: Normal Su Seviyesi, ASS: Alçak Su Seviyesi) (Turoğlu, 2017a).

Figure 3: "Narrow-High coast" and its coastal elements (DKKÇ: Marine Coastal Borderline, KKKÇ: Terrestrial Coastal Borderline, KÇ: Shoreline, YSS: High Water Level, NSS: Normal Water Level, ASS: Low Water Level) Turoğlu, 2017a).

kıyının bölümlerinden biri ya da birden fazlasının eksik olduğu kıyılardır. Bu durumdaki kıyılarda kıyı bölümlerine ait iki ya da daha fazla sınır üst üste çakışır (Turoğlu, 2017a) (Şekil 3). DarYüksek kıyı tipi doğal ya da yapay kıyı olabilir. Beton iskeleler ya da kaya dolgulardan oluşan yapay kıyılar eğer kıyının bölümlerinden biri ya da bir kaçını içermiyor ve sınır çizgilerinden bir kaçı üst üste çakışıyor ise o kıyı, doğal ya da yapay olmasına bakılmaksızın, jeomorfolojik olarak "DarYüksek kıyı" tipindedir ve güncel etken, süreç, yapı etkileşim sistemi ona göre çalışır.
Kıyının jeomorfolojik elemanları (Erinç, 1986; Erol, 1989; Bird, 2008; Davidson-Arnott, 2010; Alcantara-Carrio, vd. 2014) ve kıyının bölümlerinin tanımlayıcısı olan denizsellik indikatörü delilleri (Friedman, 1961; Andrews ve van der Lingen, 1969; Bradshaw, vd. 1989; Pinet, 1996; Edwards, 2001; Turoğlu, 2009; Erginal ve Öztürk, 2010; Turoğlu, 2010; Karunarathna, 2012; Alcantara-Carrio, vd. 2014; Turoğlu, 2017a, Avc1, 2017); k1y1 çalışmalarının temel belirleyici/tanımlayıcı dayanaklarını oluşturur. 


\section{YAPAY KIYILAR}

İnsan yapıs1 kıy1lar (Kelletat, 1995; Kobayashia, 2015), Yapay kıy1lar (Anthony, 1994; Turoğlu, 2019), Antropojenik Kıyılar (Hudson, 1980; Szabó, 2010; Li vd., 2017) gibi değişik isimler ile tanımlansa da, aslında tümünün birleştiği ve ifade ettiği temel unsur; doğrudan insan müdahalesi ve/veya insan faaliyetlerinin dolaylı sonucu olarak ortaya çıkan kıyı jeomorfolojisidir. İnsan faaliyetlerinin bir sonucu olarak, doğal karakterinden farklılaşarak gelişen bir yeryüzü şeklidir (Hudson, 1980; Szabó, 2010; Kobayashia, 2015; Li, 2017; Turoğlu, 2019). Jeomorfolojik bir ünite olan kıyının belirlenmesinde dikkate alınması gereken iki temel unsur vardır. Bu unsurlardan biri; onun belirlenmesinin gerekçelerini oluşturan geniş çerçevede fiziki coğrafya, özellikle de jeomorfolojik indikatör delilleridir (Turoğlu, 2017a). Diğeri ise kıyıyı tanımlayan kanıtların mutlak güncel olmasıdır (Turoğlu, 2017a; Turoğlu 2019). Kıyının doğal süreçlerle ya da insan müdahalesinin sonucu olarak değişmiş/değiştirilmiş (yapay kıyı) olması, yukarıda belirtilen iki temel unsurun dikkate alınma zorunluluğunu değiştirmez. Bir başka ifade ile kıyı; güncel morfodinamik etken ve süreçlerin şekillendirmeye devam ettiği, denizselliğin etkisi altındaki güncel jeomorfolojik bir ünitedir.

\subsection{Jeomorfolojik birim olarak yapay kıyılar}

Her türlü dolgular ile denizden kazanılan alanlar ve bu alanlardaki farklı amaçlar ile gerçekleştirilen yapılaşmalar, su içi yapıları, hafriyatlar ile gerçekleştirilen düzenlemeler; yapay kıyıların oluşmasına neden olan insanın doğrudan müdahaleleridir. Denize deşarj olan akarsular üzerine yapılan müdahaleler, doğrudan plajdan ya da denizden kum, çakıl çekilmesi; insanın dolaylı olarak, hatta farkında olmadan kıyının değişmesine neden olduğu faaliyetlerindendir. İnsanın doğrudan ya da dolaylı müdahalesi; kıyıdaki doğal morfodinamik etken ve süreçlerin aşındırma, taşıma ve biriktirme faaliyetlerinin değişmesine neden olur. Kıyıda etkili olan dalga ve akıntıların aşındırma, taşıma ve biriktirme sistemleri müdahale öncesine göre farklılaşır. Akarsu üzerine yapılan baraj, gölet ya da akarsudan diğer faydalanma müdahaleleri; akarsuyun denize taşıyıp getirdiği ve ağız kısmında yaptı̆̆ 1 biriktirmenin tekstür, strüktür ve nicelik özelliklerinde değişiklikler yaratır.

Plajlardan ya da denizden kum-çakıl alınması da yakınkıyı, önkıyı ve artkıyı zonlarının daralmasına hatta bunlardan bazılarının ya da tamamının ortadan kalkmasına neden olur. $\mathrm{Bu}$ gelişme; dalga ve akıntıların kıyı erozyonuna, falez gelişimine ve problemlerine, Karasal Kıyı Kenar Çizgisi (KKKÇ)'nin kara tarafına ilerlemesine, KKKÇ nin denize düşmesine, hukuki problemlerin, mülkiyet sorunlarının ortaya çıkmasına, sahil zonundaki kamusal yatırımlarının zarar görmesine neden olur.

Ayrıca kepçeler ile kosterlere deniz içinden alınan kumlar da alçak-geniş kıyı morfolojisi üzerinde aynı dinamik etkiyi yaparlar. Zira bu uygulamalar; alçak-geniş kıyı tipindeki kıyılarda, kıyı boyu ve rip akıntı sistemlerinin etkinliğini farklılaştırarak, aşınma-taşıma-birikme sistemlerini değiştirir. Kıyı erozyonu ve plajın daralması, batimetrenin değişmesi, yakınkıyı zonunun alansal ve morfolojik olarak değişikliklere uğraması, kıyı bölümlerinden deniz içine kum/çakıılların kayması-taşınması ile güncel sistemin kontrolünde, kıyı bölümleri (Şekil 2, 3) ve onlara ait sınırlar yer değiştirir.

Kıyıya yapılan antropojenik müdahaleler; hâkim rüzgârın ve en şiddetli esen rüzgârların kıyı üzerindeki süreç ve etkinliklerinde de farklılaşmalara neden olur ve bu değişiklikler de kıyının yeniden şekillenmesinde rol alırlar.

Böylece; insan müdahalesi öncesindeki morfodinamik etken ve süreçler, onların kıyı üzerindeki şekillendirici rolleri, bu etkilerin kontrolünde oluşan kıyı elemanları ve kıyı jeomorfolojisi güncelliğini yitirir. Bir başka ifadeyle artık o kıyı "Paleokıyı (Eski kıyl)" haline geçer (Turoğlu, 2019). İnsan müdahalesi ile şekillenen, güncel morfodinamik etken ve süreçlerin aktif olduğu ve onların kontrolünde gelişen, öncekinden farklı, yeni bir kıyı jeomorfolojisi (Yapay kıyı - Antropojenik kıyı) oluşmuştur. Morfodinamik etken ve süreçler; bu yeni kıyı ile uyumlu, yeni bir aşındırma, taşıma, biriktirme ve şekillendirme düzeni tesis ederler ve sürdürürler. $\mathrm{Bu}$ yaklaşım çerçevesinde; eğer kökenlerine, oluşum şekillerine göre jenetik bir kıyı tipi sınıflaması yapılacaksa, jenetik sinıflamada ayrı bir tür/tip olarak "Yapay kıyı (Antropojenik kıyı)” tipini de eklemek yanlış olmayacaktır.

Yukarıdaki açıklamalar kapsamında kıyı ve bölümlerinin, onları tanımlayan güncel, morfolojik özelliklerin esas alınmasıyla, jeomorfolojik tanımlamaları yapıldığında; Dilderesi (Kocaeli), Yenikapı ve Maltepe kıyılarındaki (İstanbul) dolgular, Karadeniz sahil yolu ve limanlar, Ordu-Giresun Havaalanı adası, vb. diğer kıyı dolgularında olduğu gibi yapay kıyılar makale konusuna ait tipik örneklerdir (Foto 1, 2, 3, 4, 5). Bu yapay kıyılar; inşaa edildiğinde, kıyının bölümlerinden birinden ya da tamamından yoksun kıyılardır. Örneğin; limanlarda (Foto 3, 5) Karasal Kıyı Kenar Çizgisi (KKKÇ), Kıyı Çizgisi (KÇ) ve Denizel Kıyı Kenar Çizgisi DKKÇ) çakışır. Diğer dolgu 


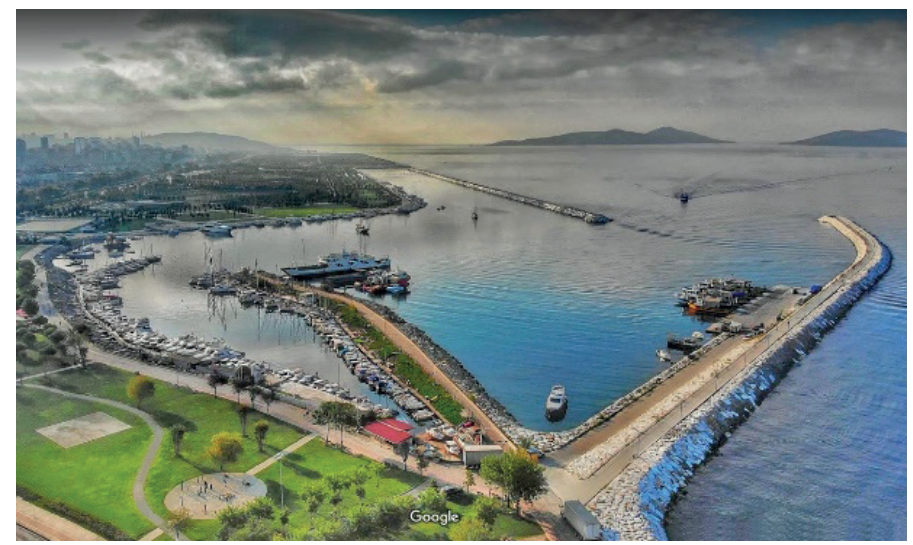

Foto 1: Maltepe dolgu alanı ve "Dar-Yüksek kıyı" tipindeki yapay kıуı (İstanbul).

Photo 1: Maltepe embankment area and artificial coast (Istanbul) in "Narrow-High coast" type.

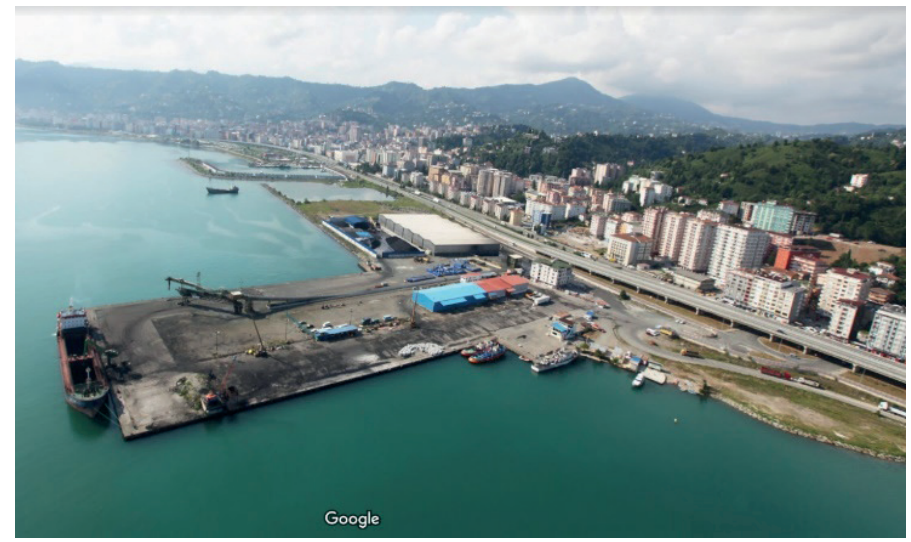

Foto 3: Rize limanı dolgu alanı, “Dar-Yüksek kıyı” tipindeki yapay kıyı. Photo 3: Rize port filling area, artificial coast in "Narrow-High coast" type

alanlarında (Foto 1, 2, 4) ise çoğu kez Kıyı Çizgisi ile Denizel Kıyı Kenar Çizgisi çakışır. Dolgu malzemesinin cinsine, yüksekliğine ve eğimine bağlı olarak değişiklik gösteren bir artkıyı zonu olabilir. Dolayısıyla; kıyının bölümlerinden birinin ya da bir kaçının eksik olması nedeni ile bu kıyılar "Dar-Yüksek yapay kıy" tipindedirler. Ancak bu durumu değişmez olarak kabul etmek mümkün değildir. Zira zaman içinde, etken ve süreçlerin şekillendirici (aşındırma, taşıma, biriktirme) faaliyetleri ile dar yüksek yapay kıyı üzerinde değişikliğe neden olarak, kıyının bölümlerinin tamamlanmasını sağlayabilir ve kıyı, alçak-geniş kıyı tipine dönüşebilir.

\subsection{Yasal boyutlarıyla yapay kıyılar}

Kıyılardan faydalanma, koruma ve kıyı yönetimi; günümüz itibarıla, 04.04.1990 tarihli 3621 sayılı kıyı kanunu (Resmî Gazete, Tarih: 17/4/1990, Sayı: 20495) ve onun uygulanmasına dair değişik tarihlerde çıkartılan çok sayıdaki yönetmelik

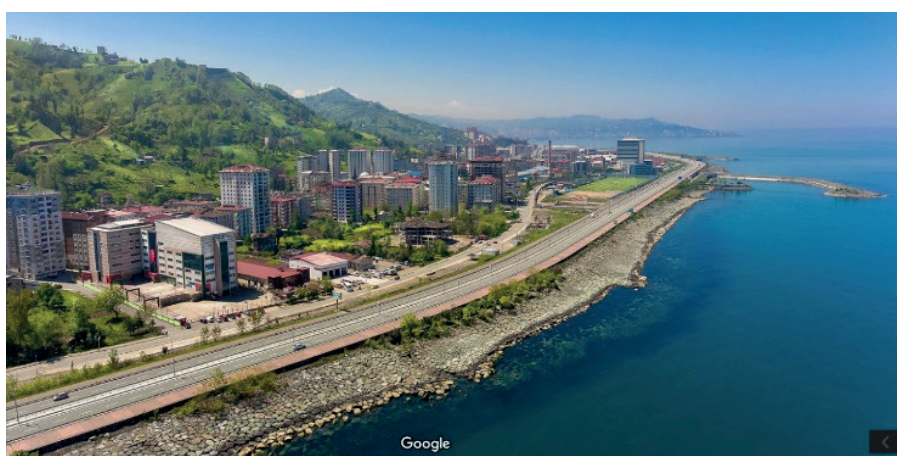

Foto 2: Doğu Karadeniz sahil yolu dolgusu ve "Dar-Yüksek kıyı" tipindeki yapay kıyı (Rize).

Photo 2: Eastern Black Sea coastal road fill and artificial coast (Rize) in "Narrow-High coast" type.

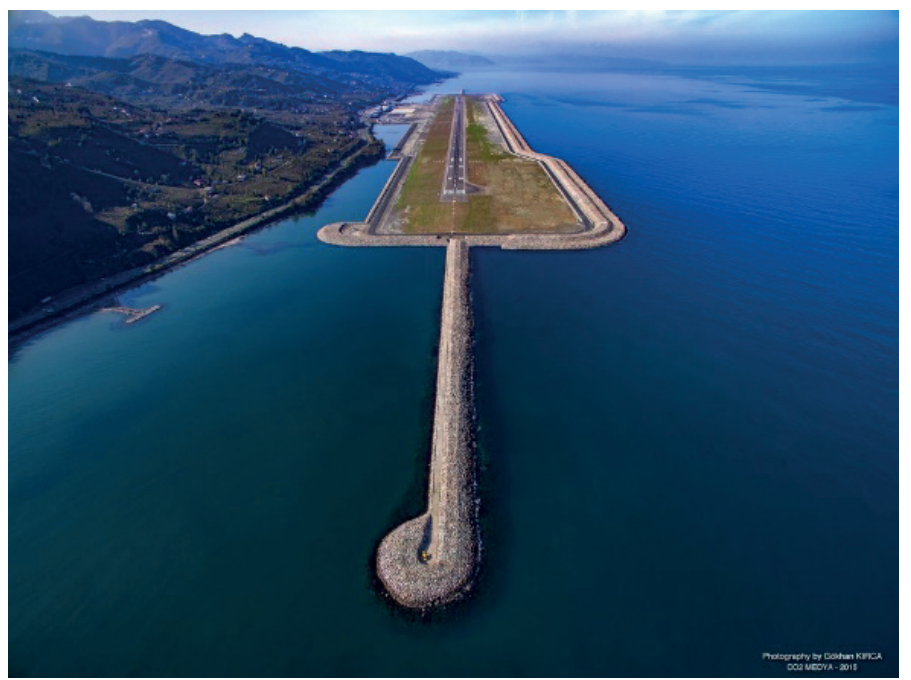

Foto 4: Ordu-Giresun Havaalanı dolgu alanı ve "Dar-Yüksek kıyı" tipindeki yapay kıyı.

Photo 4: Ordu-Giresun Airport filling area and artificial coast in "Narrow-High coast" type.

kararları yürütülmektedir. Yapay kıyılar ve yapay kıyılar ile denizden kazanılan alanların kullanımı, yönetimi ve mülkiyet koşul, kural ve standartları da yine 3621 sayılı Kıyı Kanunu ve onun uygulanmasına dair yönetmelikler ile tanımlanmış ve açıklanmıştır. Hukuki perspektifte, yapay kıyılar için önemli olan temel problem; yapay kıyının oluşturulmasıyla denizden kazanılan alanın belirlenmesine ve kullanımına yöneliktir. Doğal malzemeler ile yapılmış eski dolgu alanlarında, doğal kıyı ve KKKÇ'nin belirlenmesi çoğu kez zordur. KKKÇ’sinin; tapulu arazileri kıyı içinde bırakacak şekilde belirlenmesi halinde problem mahkemelik hale gelir. Genellikle tartışma; yapay kıyı öncesindeki, doğal KKKÇ nereden geçiyor olduğu üzerinedir. Güncel yapay kıyıya ait KKKÇ'ni belirlemek mümkündür. Ancak öncesine ait doğal KKKÇ’ni belirlemek zordur. Zira 


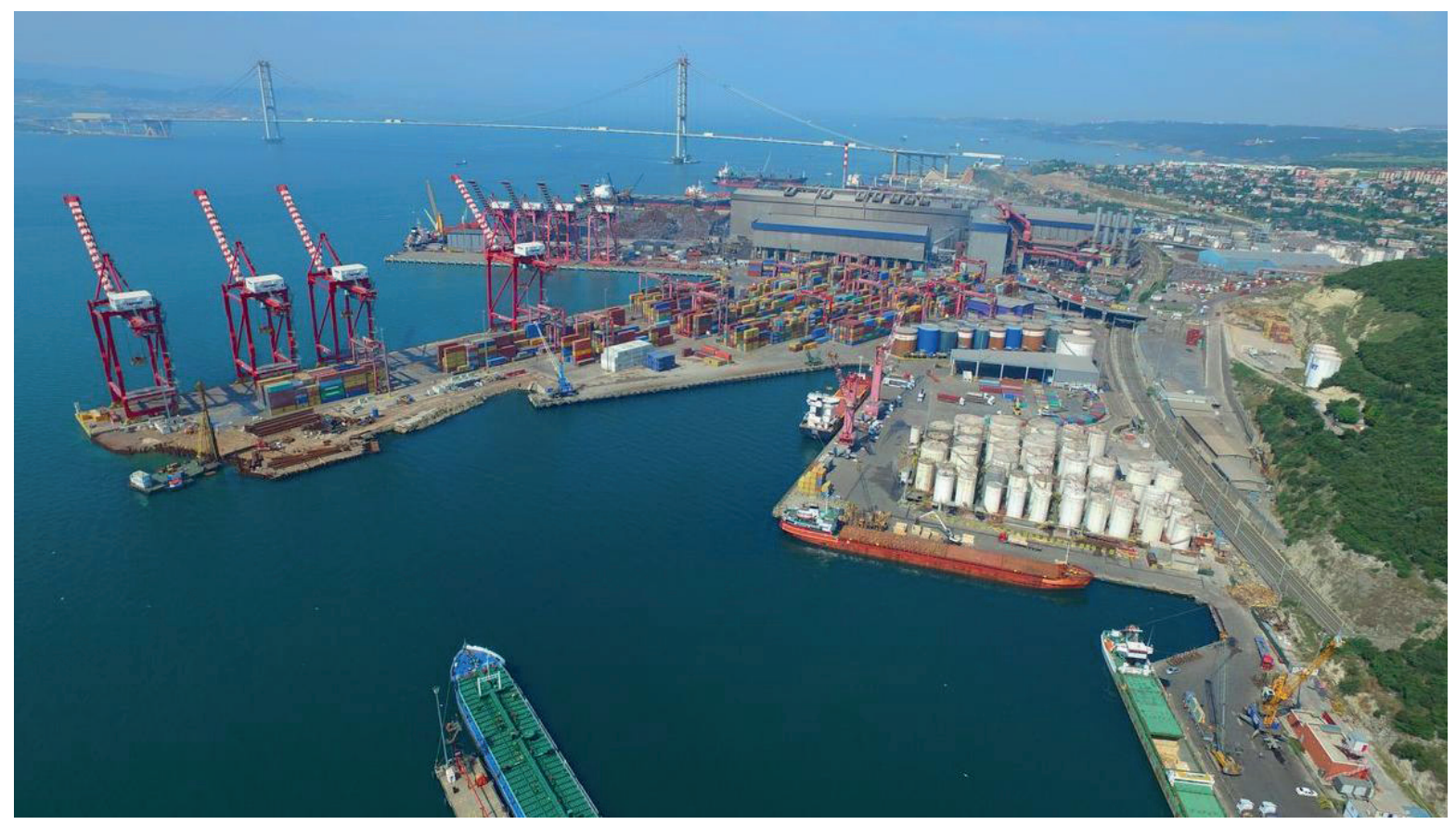

Foto 5: Diliskelesi (Kocaeli) Dolgu alanı ve "Dar-Yüksek kıyı" tipindeki yapay kıyı. Photo 5: Diliskelesi (Kocaeli) filling area and artificial coast in "Narrow-High coast" type. (http://www.turklim.org/uye/yilport-konteyner-terminali-ve-liman-isletmeleri-a-s).

büyük olasılıkla, doğal KKKÇ, yapay kıyının oluşturulması sırasında dolgu yapılmak sureti ile örtülmüş, kaybedilmiş olmalıdır. Dolgu alanının doğru şekilde belirlenebilmesi için doğal KKKÇ’nin doğru olarak belirlenmesine ihtiyaç vardır. Asliye Sulh Hukuk Mahkemelerinde, çok sayıda bu probleme ait davalar devam etmektedir.

Yapay kıyının oluşturulmasıyla birlikte, öncesine ait olan doğal kıyı, eski (paleo) kıyı niteliği kazanmıştır. Eski doğal kıyı, açık ya da örtülü olarak kıyı delilleri içeriyor olabilir. Ancak güncel morfodinamik etken ve süreçlerin şekillendirici faaliyetleri ile doğrudan ya da dolaylı olarak bir etkileşiminin kalmaması, denizselliğin güncel etkisinden tamamen uzaklaşmış olması nedeni ile eski kıyı, eski kıyının bölümleri (Şekil 2, 3) ve KKKÇ jeomorfolojik olarak güncelliğini yitirmiştir. Hukuki olarak; dava konusu olan problemlerin çözümü için eski (paleo) kıyının bu elemanları önemlidir ve belirlenmesi zorunluluğu vardır. Bu amaç için dolgu alanı ve çevresinde sondajların yapılmasına, trenç açılmasına, jeoradar ile yeraltı görüntülemelerinin yapılmasına, dolgu altındaki ve yüzeydeki eski kıyıya ait indikatör delillerin toplanmasına, bu delillere dayanarak eski kıyının dolgu altındaki alanı ve sınırlarının belirlenmesi çalışmalarına ihtiyaç vardır. Böylece doğal KKKÇ ile güncel yapay kıyıya ait KKKÇ arasındaki dolgu alanı belirlenir ve bu alanın kullanım koşulları ve mülkiyet esasları için yasal çerçevedeki prosedür uygulanır.
Yukarıda da belirtildiği üzere; "Kıyı Kenar Çizgisi (KKÇ)" konusu; 3621 sayılı Kıyı Kanunu ve onun uygulanmasına dair ilgili yönetmeliklerde yer alan önemli maddelerden birisidir. Kıyı Kanununun, "Tanımlar, Madde 4, (Değişik: RG30/3/1994-21890, Madde 1) Kiyı Kenar Çizgisi" açıklamasında; "Bu sınır doldurma suretiyle arazi elde edilmesi halinde de değiştirilemez." ifadesi yer alır (Turoğlu, 2017b). Adı geçen kanunda belirtilen KKÇ; Karasal Kıyı Kenar Çizgisi (KKKÇ) olup, sabit ve değiştirilemez olduğunu belirten bu ifade; jeomorfolojik olarak güncel kıyı tanımlaması kapsamında hatalıdır. Zira KKKÇ'leri doğal ya da yapay sebeplerden dolayı zaman içinde değişebilir. Eğer antropojenik sebeplerle KKKÇ değişmiş ise doldurularak kazanılan alanının kullanımı ve mülkiyetine ait hukuki problemlerin çözümü için dolgu öncesi doğal kıyı ve onun kara tarafındaki sınırı olan eski doğal KKKÇ’nin belirlenmesine ihtiyaç duyulmaktadır. Dolayısıyla, yapay kıyılarda, güncel kıyı ve kıyının sınırlarının jeomorfolojik olarak belirlenmesi başka bir konudur, mahkemelerde devam eden davalara konu olan; dolgu yapılarak kazanılan alanın mülkiyet problemlerini çözmek için "Kıyı Kenar Çizgisi değişmez" ifadesi ve bunun uygulanması ise başka bir konudur. $\mathrm{Bu}$ ayırım ve vurgu yapılmadan, ilgili yasa ve yönetmeliklerdeki ' KKÇ’nin değiştirilemez" olduğu ifadesi uygulamada önemli hatalara yol açan kararlara neden olmaktadır. 


\section{DILISSKELESİ KIYILARININ JEOMORFOLOJISİ}

Antropojenik değiş̧ikliklerin olmadığı, doğal jeomorfolojik karakterin korunduğu ve doğal jeomorfolojik etken ve süreçlerin aşındırma, taşıma ve biriktirme yaparak şekillendirmeye devam ettiği dönemlerde, Diliskelesi bölgesi; yukarıda ana hatları ile tanımlaması yapılan "Geniş-Alçak" ve "Dar-Yüksek" doğal kıyı türlerinin her ikisinin de görüldüğü kıyılardır (Foto 6, 7, 9, 10, 12, 14).
Çalışma sahasının batısından itibaren, doğu istikametinde; $71 \mathrm{~m}$ rakımlı tepenin güneybatı, güney ve güney doğu yamaçları ile temsil edilen Kaba Burun, sonra 98 rakımlı Adatepe'nin dik güney yamaçları ve en doğuda ise $76 \mathrm{~m}$ seviyelerindeki sırtın güney ve güneydoğu dik yamaçları "Dar-Yüksek kıyı" tipindedir (Şekil 4), (Foto 6, 7, 12). Bu kıyılar; yakın kıyıdan yoksun, dar bir önkıyı zonu ve genişliğini yamaç eğim derecesinin belirlediği, artkıyı zonuna sahiptir. 1960 l1 yıllar öncesinde bu dar-yüksek kıyılarda artkıyı zonunun genellikle çok dar olduğu

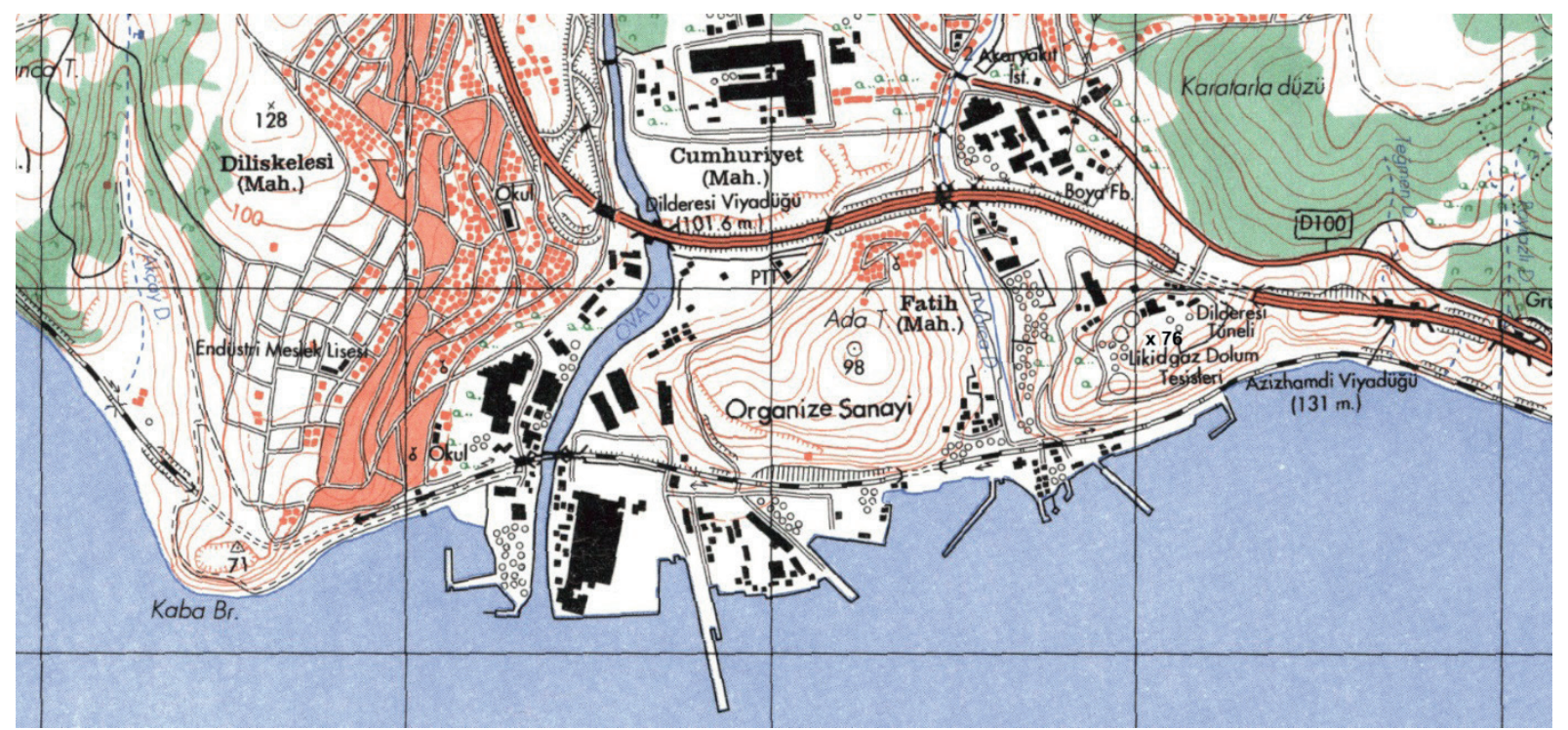

Şekil 4: 1972 tarihli 1/25000 ölçekli topografya haritasında Diliskelesi kıyıları.

Figure 4: The coast of Diliskelesi in 1:25000 scale topography map dated 1972.

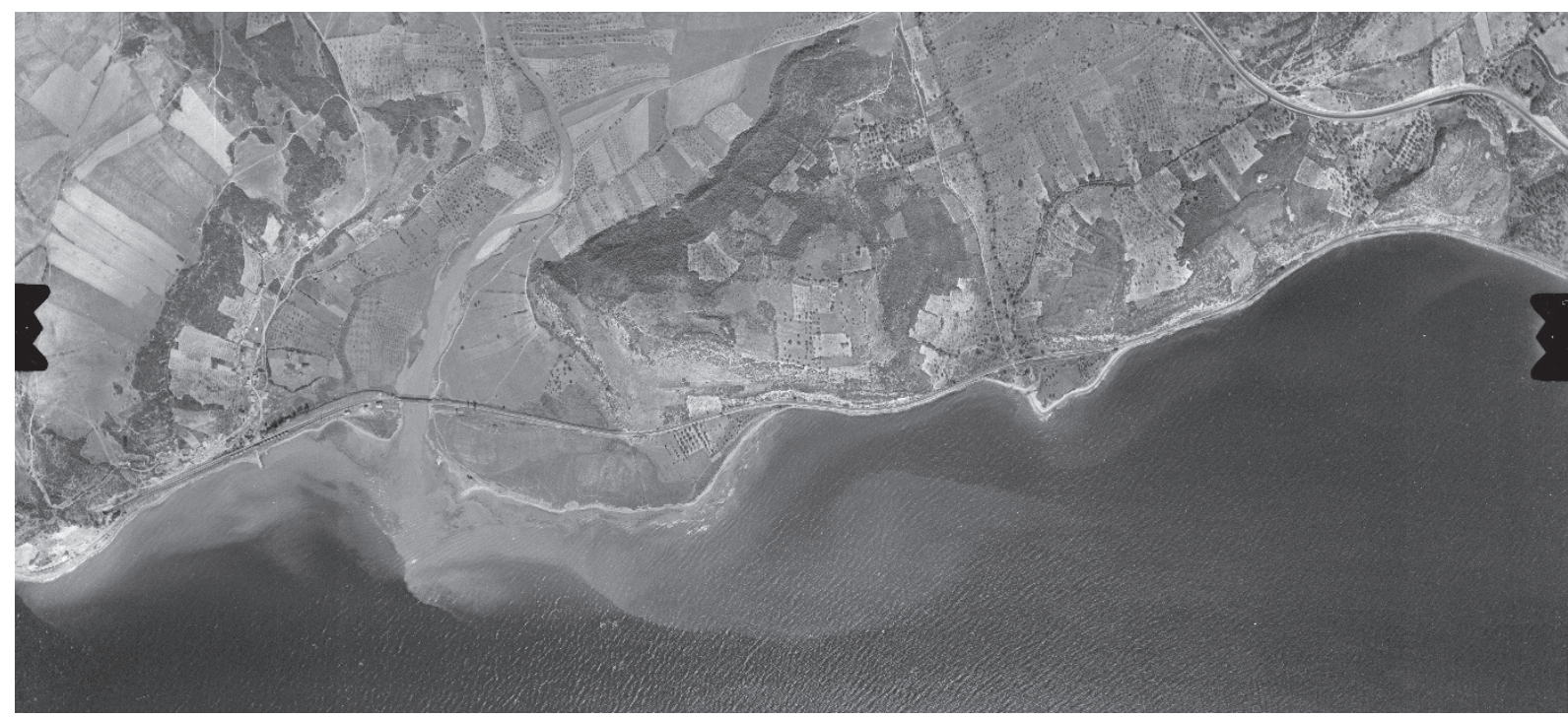

Foto 6: 1962 yılına ait 1/18000 ölçekli hava fotosu. Bölgede, doğal kıyıya yapılan ilk insan müdahalesi; kıyı boyunca devam eden tren yolunun inşaatı sırasında gerçekleşmiştir. Buna rağmen o dönemlerde yapılan bu müdahale doğal kıyının genel karakterini çok fazla değiştirmediği, o döneme ait hava fotolarından anlaşılmaktadır.

Photo 6: 1/18000 scale aerial photo of 1962. In the region, the first human intervention to the natural coast occurred during the construction of the railway along the coast. Nevertheless, it is understood from the aerial photos of 1962 that this intervention did not change the general character of the natural coast too much. 


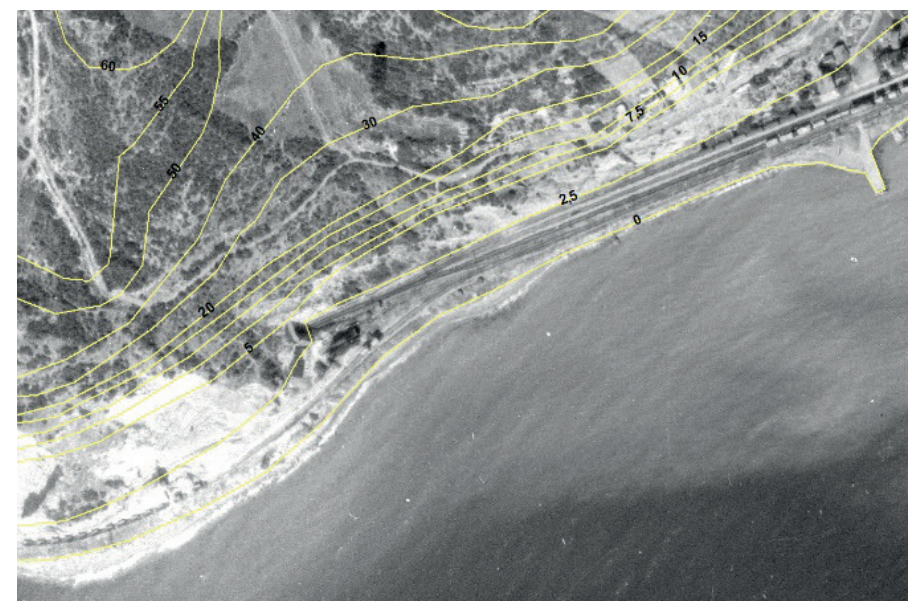

Foto 7: 1962 yılı hava fotosunda Kaba Burun kıyıları, eski tren yolu ve tünel.

Photo 7: Kaba Burun coast, old railroad and tunnel in the 1962 aerial photo.

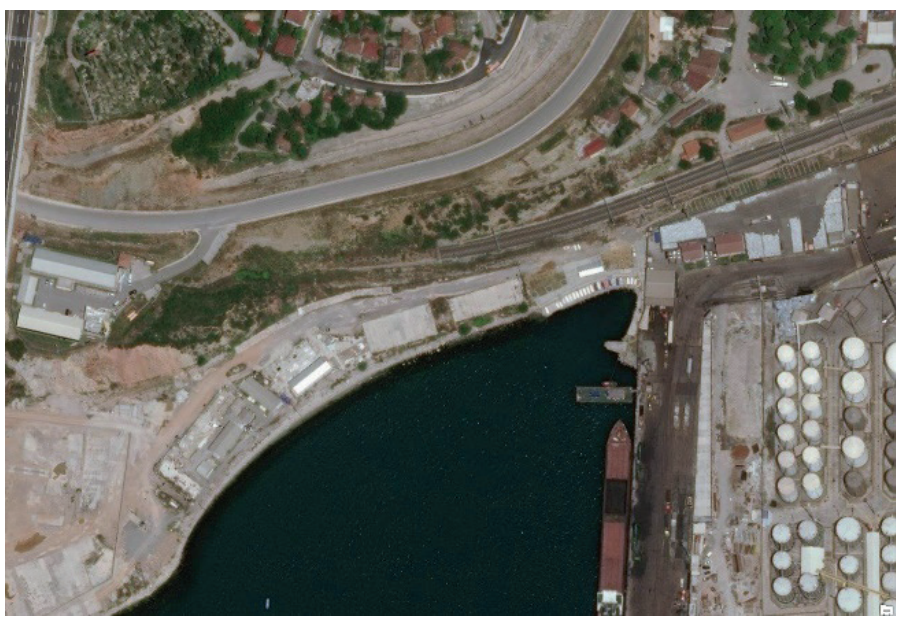

Foto 8: Güncel Kaba Burun tüneli ve dar-yüksek yapay kıyı jeomorfolojisi.

Photo 8: Current Kaba Burun tunnels and narrow-high artificial coast geomorphology.

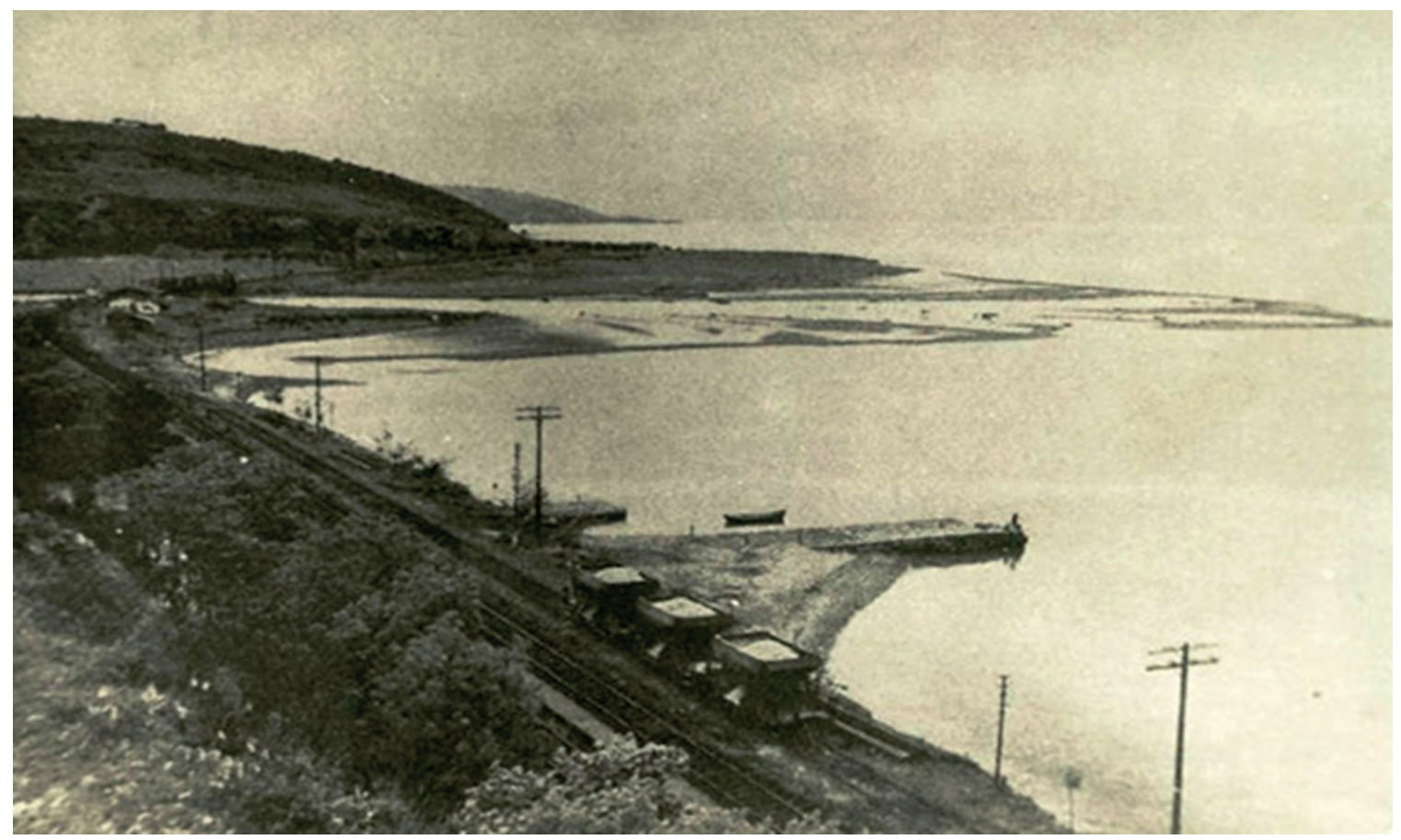

Foto 9: 1960'ı ıılların başı. Arif Müfit MANSEL arşivine ait bu fotoğrafta Dilovası geniş-alçak kıyı tipi (Fotoğrafın üst bölümünde görülen geniş düzlük) ve 98 rakımlı Ada Tepe'nin güney yamaçları görülmektedir. Yakın planda ise Diliskelesi görülüyor. Fotoğraftaki akarsu ağızı Dilderesi'dir. Kazı ve dolgu yapılmak sureti ile oluşturulan o tarihlerdeki dar demiryolu platformu kıyı boyunca devam etmektedir.

Photo 6: The beginning of the 1960s. This photograph from the Arif Müfit MANSEL's archive shows the Dilovası large-low coast type (the large flat in the upper part of the photo) and the southern slopes of Ada Tepe $(98 \mathrm{~m})$. Diliskelesi is seen in the near plan. The river mouth on photo is Dilderesi. The narrow railway platform, which was formed by excavation and filling, continues along the coast.

ya da kıyının artkıyı zonundan yoksun olduğu görülmektedir. 1960 lı yıllarda doğal kıyı; sadece dar bir önkıyı zonu ile temsil edilmektedir. Kıyıdan geçen eski demiryolu inşaatı sırasında dar-yüksek kıyı bölgelerinde, yamaçların alt seviyelerinde yapılan hafriyat ve denize yapılan dolgular ile demiryolu güzergâhı için yeterli olacak kadar dar bir platform oluşturulmuştur (Foto 6, 7, 9, 10, 12, 14). 1960 l1 y1lların başlarında, batıdaki 71m rakımlı Kaba Burun dar-yüksek kıyısı 


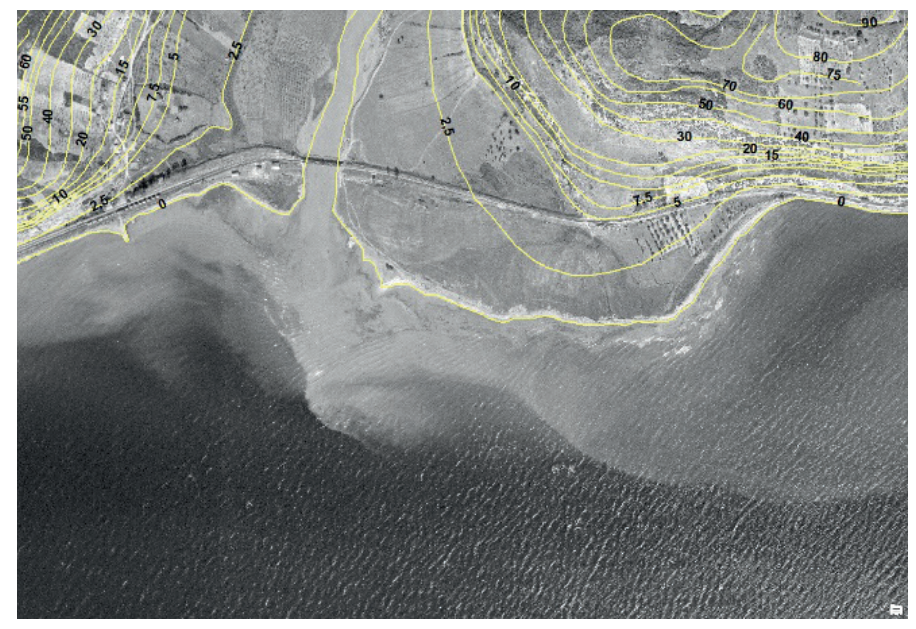

Foto 10: 1962 tarihli hava fotosunda Dilderesi ağızı, geniş-alçak doğal kıyı jeomorfolojisi.

Photo 10: Dilderesi mouth in 1962, large-low natural coast geomorphology.

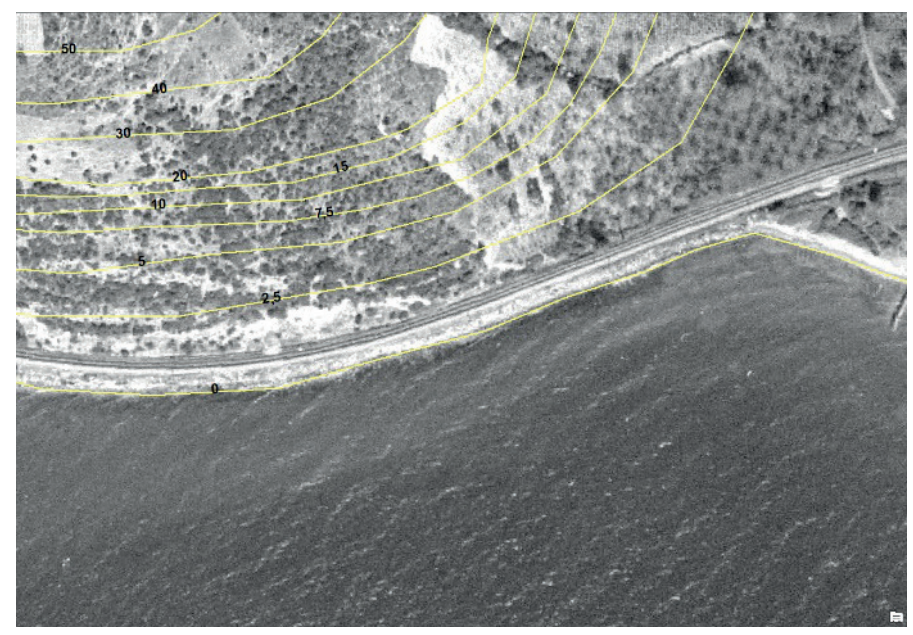

Foto 12: 1962 yılı hava fotosunda Ada Tepe güney yamacındaki dar-yüksek kıyı ve yamaçta hafriyat ile oluşturulan tren yolu dar platformu.

Photo 12: Narrow-high coast on the southern slope of Ada Tepe in 1962. And the railway line's narrow platform formed by the excavation.

bir tünel geçişi ile sağlanmıştır (Şekil 4'te kesik çizgiler ile görülmektedir). Tünel kazısı ile çıkan hafriyat malzemeleri ise hemen kıyıya dökülerek ön kıyı zonu genişletilmiştir. Benzer durum Adatepe dar-yüksek kıyılarında da yapılmıştır. Şekil 4'te 98 rakımlı Adatepe güneyinde tarama ile gösterilen diklik, tren yolu inşaatı sırasında yamaçta yapılan hafriyat dikliğini göstermektedir. 1970 yllında, bu kez Adatepe'nin güneyinde ikinci tünel açılmıştır. Hem yamaç hafriyatından çıkan ve hem de tünel hafriyatından çıkan kazı malzemeleri kıyıdan denize dökülerek dar önkıyı zonu doldurulmuş ve yapay kıyı oluşturulmuştur (Foto 12, 13, 14, 15, 16).

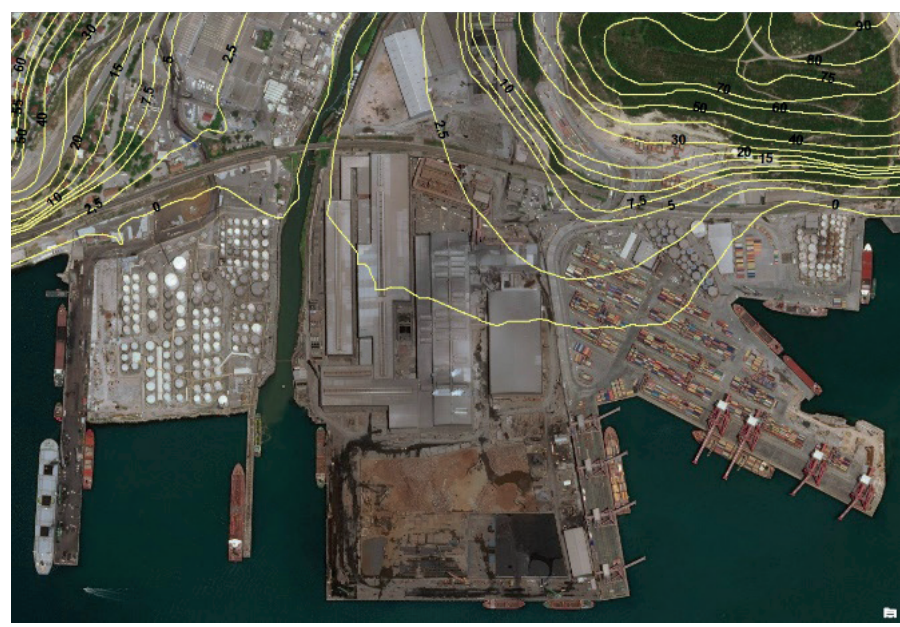

Foto 11: Değiştirilmiş Dilderesi ağızı, güncel Dilovası kıyıları ve doldurulmak sureti ile oluşturulan dar-yüksek yapay kıyı jeomorfolojisi.

Photo 11: Modified Dilderesi mouth, current Dilovasi coast and narrowhigh artificial coast geomorphology, created by filling.

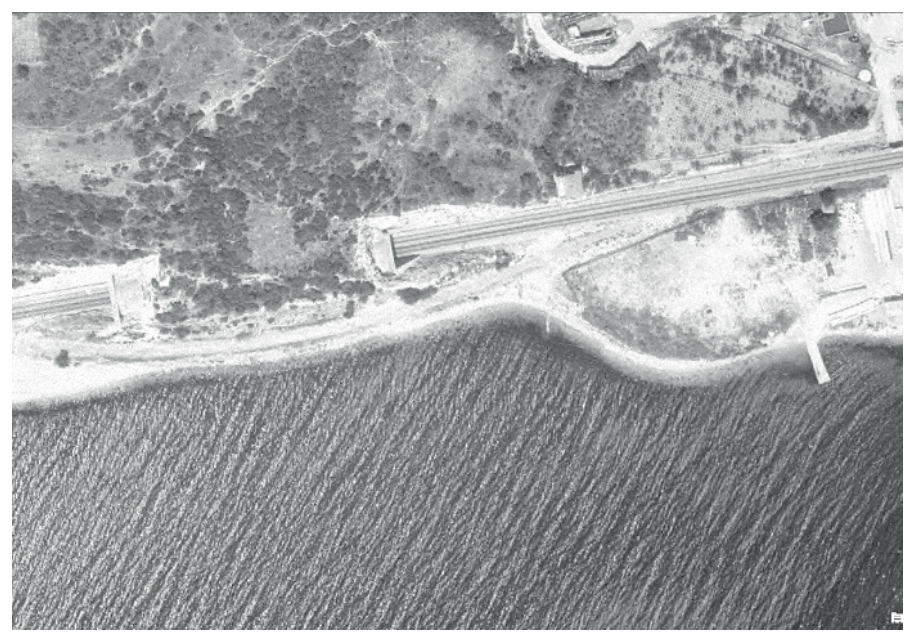

Foto 13: 1976 yılı hava fotosunda "Ada Tepe tüneli" ve yapay kıyının oluşumu. Kıyı ile tünel arasındaki iz; eski tren yolu platformudur.

Photo 13: The Ada Tepe Tunnel and the formation of the artificial coats in the 1976. Trail between the coast and the tunnel is the old railroad platform.

Diliskelesi bölgesinde, dar-yüksek kıyı tipi akarsu ağızlarında iki kez kesintiye uğramış ve kıyının bu bölümlerinde geniş-alçak kıyı tipi gelişmiştir. Bunlardan biri; batıda Kaba Burun $(71 \mathrm{~m})$ ile Adatepe (98m) arasındaki Ova Dere (Dil Deresi) vadisi ağızında (Foto 6,9,10) ve diğeri ise doğuda Narca Dere ağzındadır (Foto 6, 14). 1960 lı yılların başlarında, tren yolu inşaatı sırasında, yamaçlarda yapılan kazılardan ve tünel kazılarından çıkan hafriyat malzemelerinin dökülmesi ile başlayan doldurma işlemleri bu kıyılardaki doğal kıyının değiştirilmesine, yapay kıyı oluşumunun gerçekleşmesine neden olmuştur (Şekil 4; Foto 6, 7, 8, 9, 13, 15, 16). 


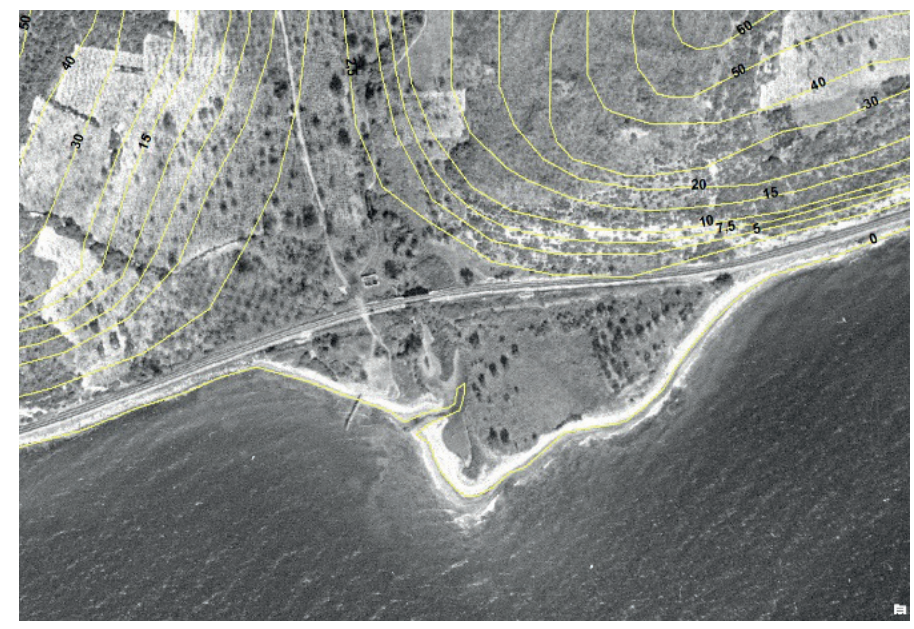

Foto 14: 1962 tarihli hava fotosunda Narca Dere ağızı, delta düzlüğü ve geniş-alçak kıyı tipindeki doğal kıyı.

Photo 14: Narca Creek mouth, delta plain and natural coast as largelow coast type in 1962.

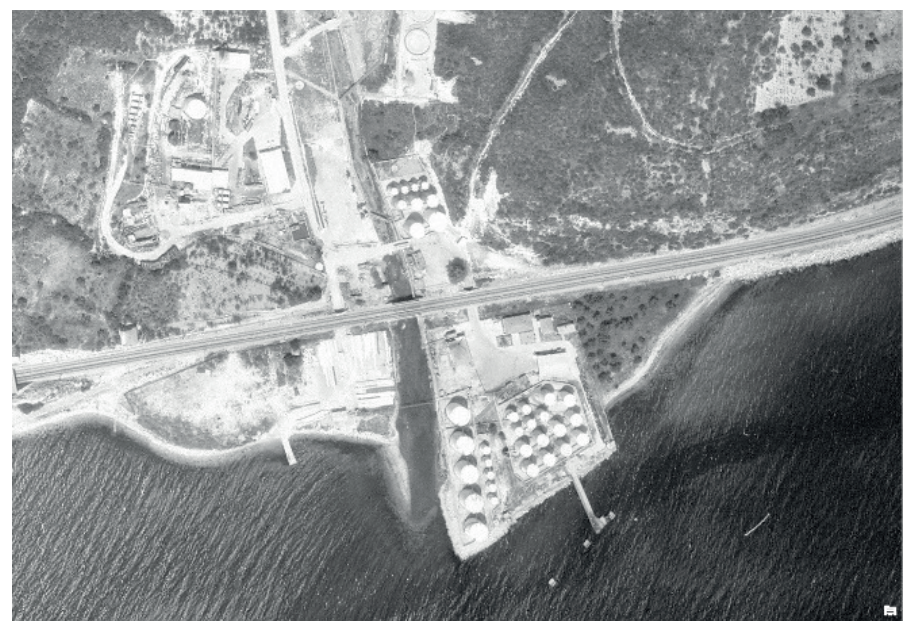

Foto 15: 1976 tarihli hava fotosunda Narca Dere ve değiştirilmiş ağızı, yamaç hafriyatı ve tünel kazısından çıkan malzemeler ile oluşturulan dar-yüksek yapay kıyı.

Photo 15: Narca Creek and its modified mouth in 1976. The narrowhigh artificial coast formed by slope and tunnel excavation materials.

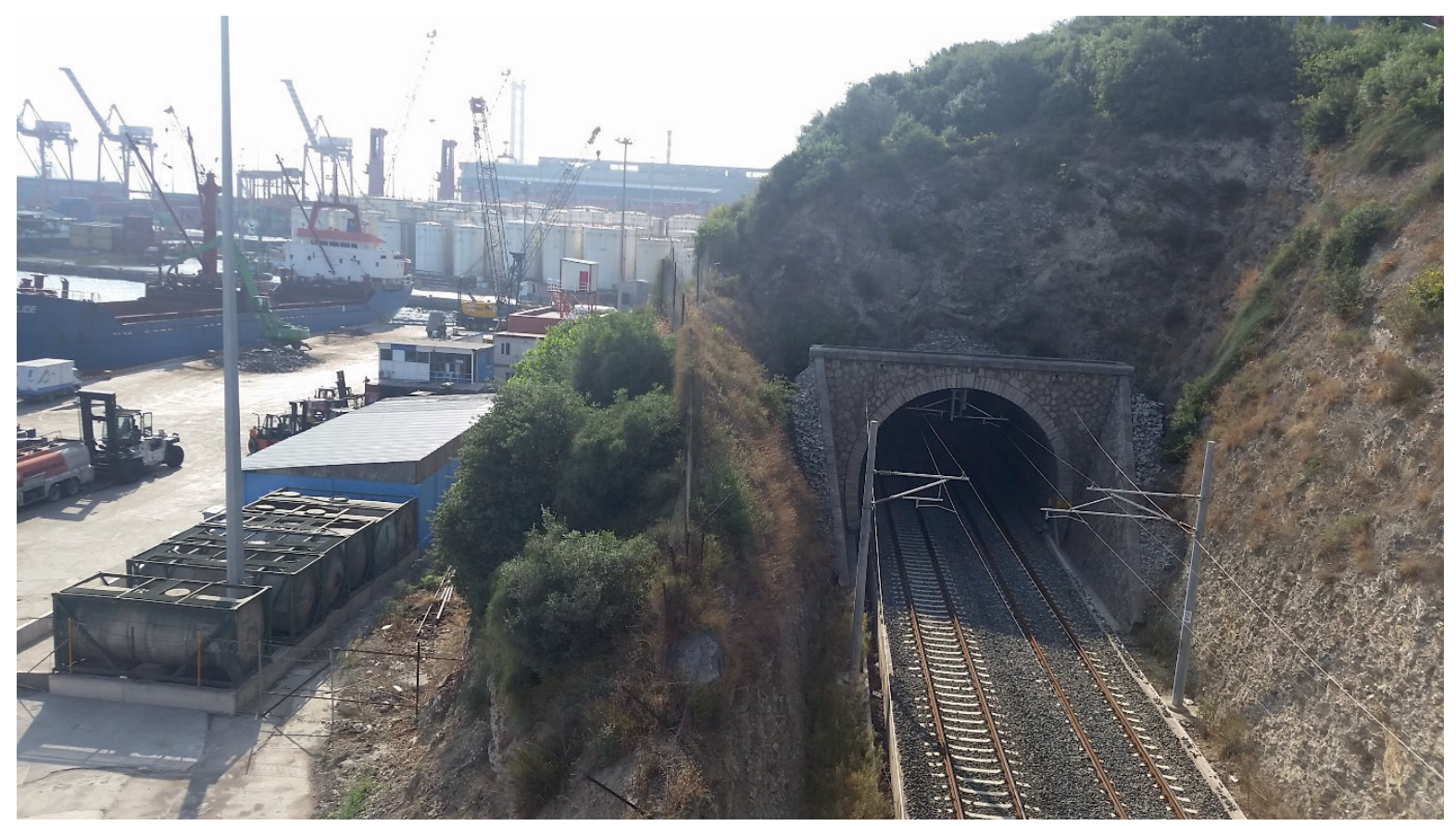

Foto 16: Ada Tepe tüneli, doğal yamaç eğimi, dolgu alanı ve gemilerin yanaştığı dar-yüksek yapay kıyı.

Photo 6: Ada Tepe tunnel, natural slope inclination, fill area and narrow-high artificial coast where ships are docked.

Çalışma sahasının doğu bölümünde dolgu sahasının belirlenmesi amacıyla sondajlar yapılmıştır (Şekil 5). Sondajlar ile dolgu malzemesi, denizel sedimentler ve denizel ortam tanımlayıc1 delilleri ve anakaya tespitlerinin yapılması amaçlanmıştır. Sondaj sonuçları Tablo 1 de verilmiştir. 1, 2, 3, 4, 5,8 ve 9 nolu sondajlarda denizel ortam çökellerine ait örnekler kesilmiştir (Tablo 1). Şekil 6 da sondaj lokasyonlarının 1962 tarihli hava fotosundaki lokasyonları görülmektedir. $\mathrm{Bu}$ çakıştırma (Şekil 6) görseli de 1, 2, 3, 4 ve 9 nolu sondajların deniz içinde, 5 ve 8 nolu sondajların ise denizselliğin etkisi altındaki kıyı içinde kaldığını göstermekte ve dolayısıyla, Tablo 1 deki sondaj sonuçlarını doğrulamaktadır. 6, 7 ve 10 nolu sondajlarda dolgu malzemesinden sonra doğrudan anakayanın kesilmesi (Tablo 1); bu sondaj lokasyonlarının daha önce denizselliğin etkisi altına kalmadığının göstergesi, delilleridir (Şekil 5, 6). 


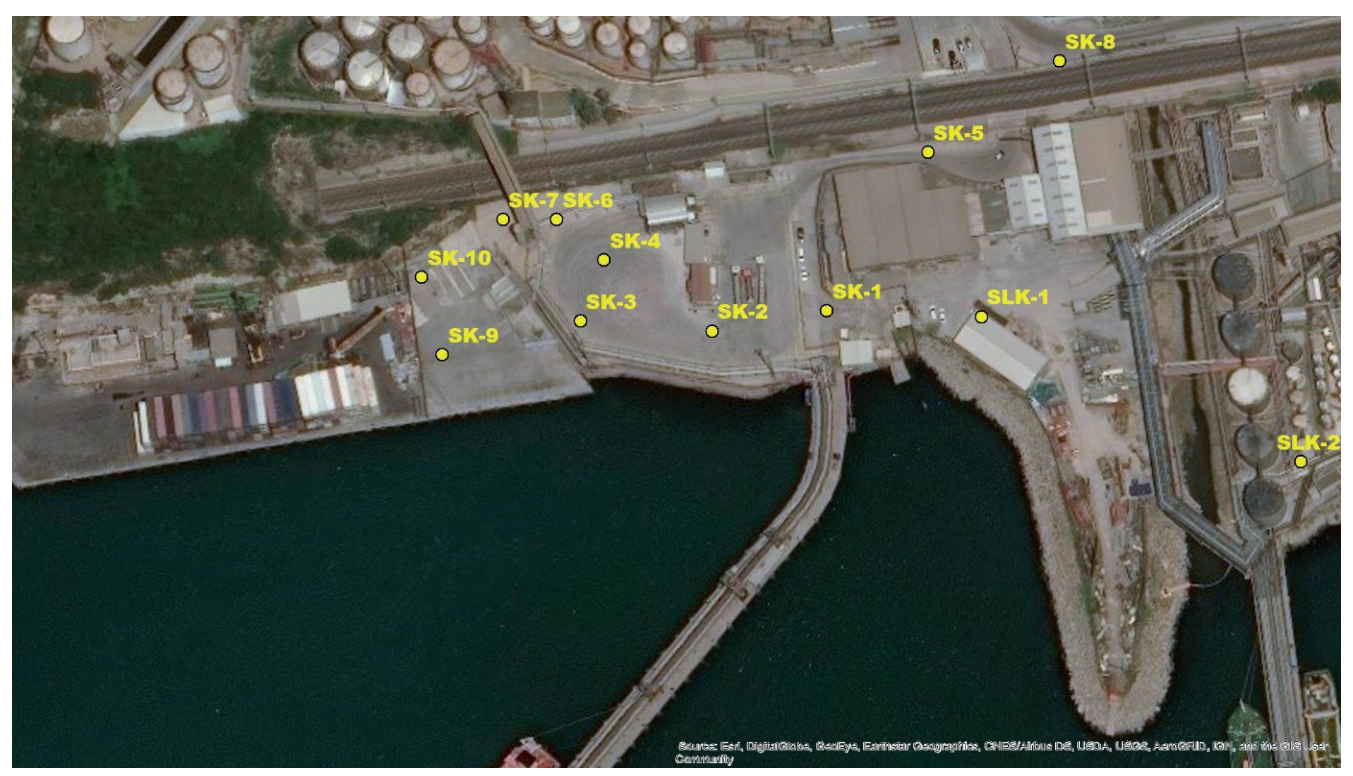

Şekil 5: Narca Dere ağızı ve yakın çevresi güncel yapay kıyı ve yakın çevresinde yapılan sondajların lokasyonları (SK1-SK10). Figure 5: The current artificial coast, the locations of the drillings (SK1-SK10) performed in the Narca Creek mouth and its close vicinity.

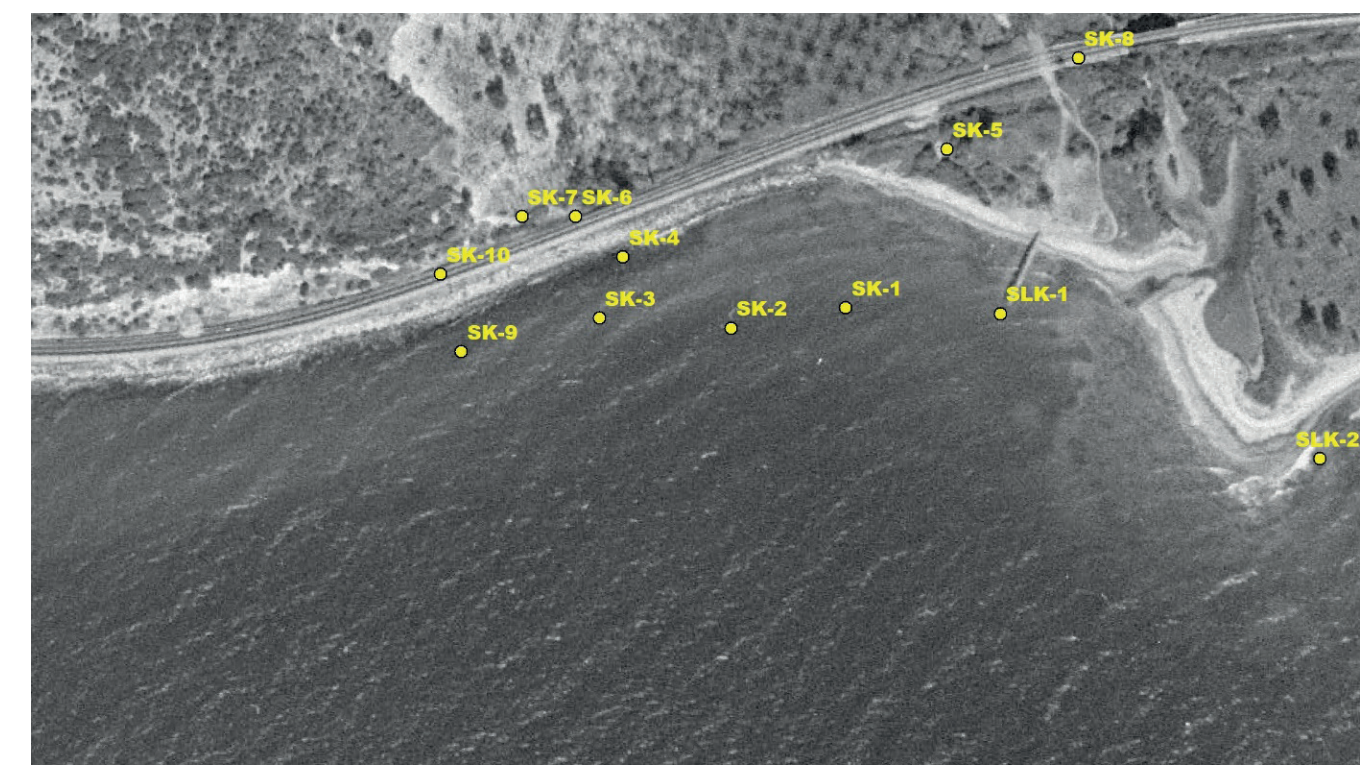

Şekil 6: Narca Dere ağızı ve yakın çevresi güncel yapay kıyı ve yakın çevresinde yapılan sondajların (SK1-SK10) 1962 yılı hava fotosundaki lokasyonları.

Figure 6: The locations of the drillings (SK1-SK10), performed in the Narca Creek mouth, its close vicinity and the current artificial coast, on 1962 aerial photo.

\section{KIYI TIPİ VE ÖZELLIKKLERI}

Diliskelesi kıyıları; yukarıdaki amaca yönelik ihtiyaçlara cevap verecek yeterliliklere uygun olarak, denizin insan tarafindan doldurulması sonucunda oluşturulan yapay kıyılardır (Şekil 1, 4, Foto 6). Doğal kıyı tanımlayıcı delillerini ve niteliklerini tamamen kaybetmiş, geri dönüşü mümkün olmayan değişime uğramış kıyılardır. Dar-yüksel doğal kıyılar doldurularak doğal dikliklerin etek kısımlarından itibaren, deniz seviyesinden $\pm 2,00 \mathrm{~m}$ yüksekliğinde beton platformlar oluşturulmuştur (Foto $5,7,8,10,11,14,15)$. Bu platformların deniz suyu ile temas ettikleri iskele bölümlerinde ortalama derinlikler, büyük tonajlı gemilerin su kesinime uygun olacak şekilde 4,00-7,00m arasında değişmektedir (Şekil 7). Geniş-alçak doğal kıyılarda da kara taşıtları için yükleme, manevra, depolama amaçlı beton platform oluşturmak üzere, yeterli su derinliğine ulaşılacak mesafe ve alan için dolgu yapılarak kıyı değiştirilmiş ve yapay kıyı oluşturulmuştur (Şekil 4, 5, Foto 5, 11, 16). 
Tablo 1: Sondaj lokasyonları (UTM koordinatlardır) ve genelleştirilmiş sondaj logları.

Table 1: Drilling locations (UTM coordinates) and generalized drilling logs.

\begin{tabular}{|c|c|c|c|c|c|c|c|c|c|c|}
\hline & SK-1 & SK-2 & SK-3 & SK-4 & SK-5 & SK-6 & SK-7 & SK-8 & SK-9 & SK-10 \\
\hline$x$ & 4515097 & 4515091 & 4515094 & 4515112 & 4515144 & 4515124 & 4515124 & 4515171 & 4515084 & 4515107 \\
\hline $\mathbf{Y}$ & 0461353 & 0461319 & 0461280 & 0461287 & 0461383 & 0461273 & 0461257 & 0461422 & 0461239 & 0461233 \\
\hline $\mathbf{Z}$ & $4,12 \mathrm{~m}$ & $5,30 \mathrm{~m}$ & $5,30 \mathrm{~m}$ & $5,51 \mathrm{~m}$ & $2,95 \mathrm{~m}$ & $5.58 \mathrm{~m}$ & $5,52 \mathrm{~m}$ & $4,68 \mathrm{~m}$ & $3,74 \mathrm{~m}$ & $3,98 \mathrm{~m}$ \\
\hline \multicolumn{11}{|l|}{$6 m$} \\
\hline 5 & & $5,30 m$ & $5,30 \mathrm{~m}$ & $5,51 m$ & & $5,58 m$ & $5,52 m$ & & & \\
\hline 4 & \multirow[t]{2}{*}{$4,12 m$} & & & & & \multirow[b]{2}{*}{ Dolgu } & \multirow{2}{*}{$\begin{array}{c}\text { 4,92m } \\
\text { Anakaya }\end{array}$} & \multirow[t]{2}{*}{$4,68 m$} & & \\
\hline 3 & & & & & $2,95 m$ & & & & $3,74 m$ & $3,98 m$ \\
\hline $\begin{array}{l}2 \\
1\end{array}$ & Dolgu & Dolgu & Dolgu & Dolgu & Dolgu & & & Dolgu & Dolgu & $\begin{array}{c}2,48 m \\
\text { Anakaya }\end{array}$ \\
\hline 0 & & & & & & $1,58 \mathrm{~m}$ & & & $\overline{0,5} \overline{4} \bar{m}$ & \\
\hline-1 & & & & $-0,79 m$ & $-0,4 m$ & Anakaya & & & Denizel & \\
\hline-2 & & $-1,70 m$ & $-1,00 m$ & Denizel & Denizel & & & $-1,52 m$ & & \\
\hline-3 & $-3,68 m$ & Denizel & Denizel & & & & & Denizel & & \\
\hline-4 & Denizel & & & & & & & & & \\
\hline-5 & & & & & & & & & & \\
\hline
\end{tabular}

Foto 6 da görülen doğal kıyı, Şekil 1 de görülen kıyıya dönüştürülmüştür. Güncel yapay kıyıda, kıyı kenar çizgileri (Şekil 2, 3); Denizel Kıyı Kenar Çizgisi (DKKÇ), Kıyı Çizgisi (KÇ) ve Karasal Kıyı Kenar Çizgisi (KKKÇ) çakışmaktadır. Çalışma sahası kıyılarında; kıyı bölümleri olan "Yakınkıyı", "Önkıyl", "Artklyı" yoktur. Bu kıyılarda ve liman içinde, iskele betonuna temas eden suyun derinliği; liman içindeki en büyük dalga derinliğinden (Dalga derinliği; maksimum dalga boyunun yarısı kadardır) fazla olup, dalga tabanının deniz tabanına temas etme ve şekillendirme etkisi olmaz. Gemilerin yanaştı̆̆ iskele önlerinde su derinliklerinin (Batimetri) 4-7m civarında değiştiği, kısa mesafede su derinliğinin $12 \mathrm{~m}$ lere ulaştığı ölçülmüştür (Şekil 7). Bu sebepten dolayı su hareketlerinin deniz tabanını şekillendirici etkisi olmadığı/olamadığı için çalışma sahasının yapay kıyılarında "Yakınkıyı" yoktur. $\pm 2,00 \mathrm{~m}$ yüksekliğinde beton platformlar gemilerin yanaştı̆̆ iskele ile son bulur. Deniz
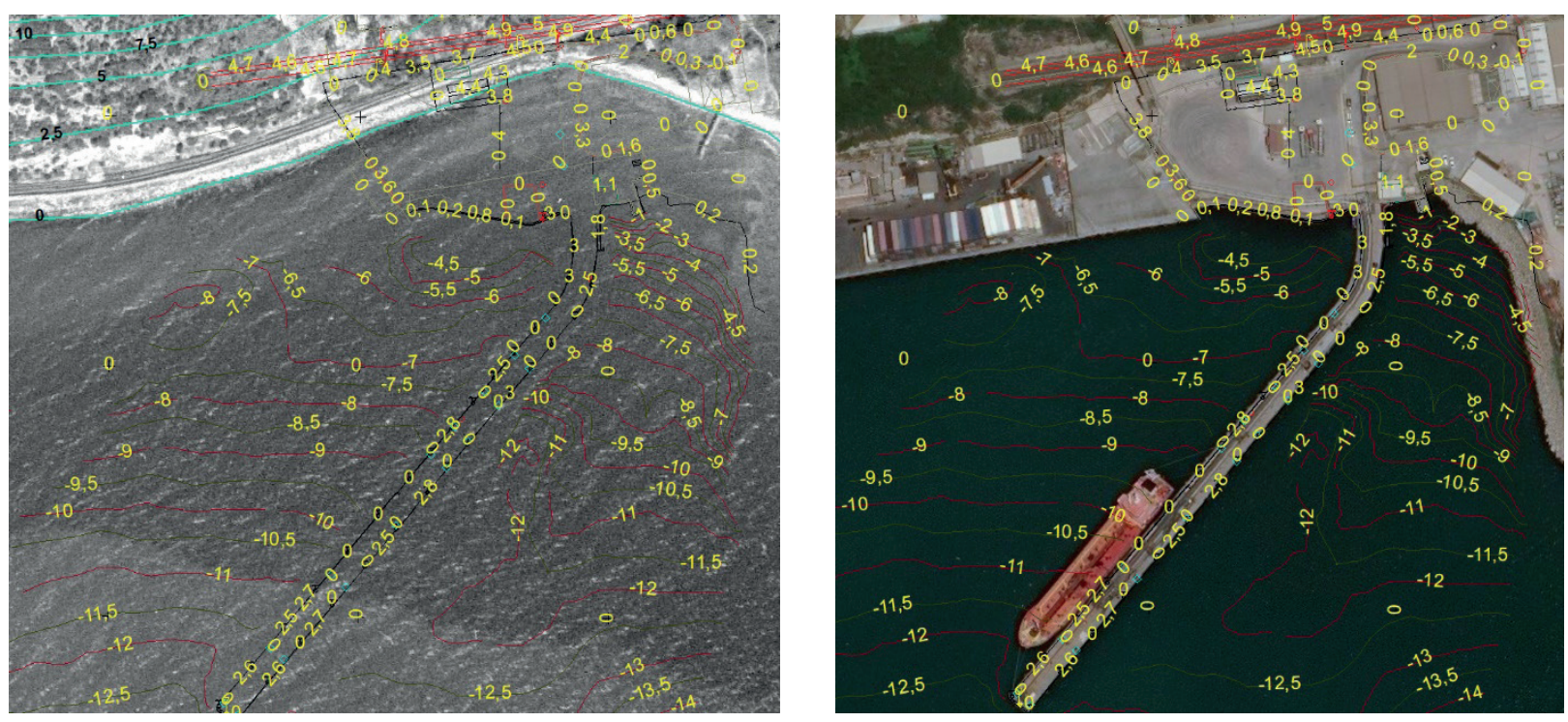

Şekil 7: Narca Dere ağızı ve yakın çevresi kıyıları (A: 1962 hava fotosu, B: Güncel) ve batimetrik özellikleri.

Figure 7: Narca Creek mouth and close vicinity coast (A: 1962 aerial photo, B: Current) and its bathymetric features. 
suyu seviyesinin en yüksek olduğu ve en fazla çekik olduğu seviyelere ait kıyı çizgisi; deniz suyu yüzeyine dik inen iskele betonunu takiben, düşey doğrultuda alçalmak ve yükselmek sureti ile yatay yönde yer değiştiremeden hareket eder. Kıyı çizgisinde yatay yönde bir değişiklik olmaması nedeni ile "Önkıyı" da yoktur. Deniz suyu seviyesi hiçbir zaman iskele tabliye betonu seviyesine kadar yükselmez ve beton platform üzerinde yayılmaz (Şekil 7, Foto 16).

Diliskelesi kıyıları boyunca yer alan ve deniz seviyesinden $\pm 2,00 \mathrm{~m}$ yüksekliğindeki yükleme, manevra, depolama amaçlı beton platfom (Foto 5, 8, 11, 16), günümüz itibarıla; denizselliğin etkisine ait hiçbir kıyı tanımlayıcısı denizsellik indikatör deliline de sahip değildir. Deniz, rüzgâr, akarsu etkinliğine ait delil içermez. Zaten fonksiyonel özelliği itibarıyla bunun olamayacağ 1 koşullarda projelendirilmiş ve inşaa edilmiştir ve doğal kıyı niteliğini kaybetmiştir. Dolayısıyla, bu kıyılar (Şekil 1, 4, 5, 7; Foto 5, 8, 11, 16) DKKÇ, KÇ ve KKKÇ’nin üstüste çakıştığı, Dar-Yüksek Kıyı tiplerinde görülen güncel morfodinamik etken ve süreçlerin karakteristik şekillendirici faaliyetleri ile aktiftirler.

\section{SONUÇ}

İnsan tarafindan doldurularak oluşturulan yapay kıyılarda; kıyı morfolojisi, akıntı sistemleri, dalgaların ve rüzgârların ve hatta akarsuların ağız kısımlarındaki etkinliği, morfodinamik etken ve süreçlerin kontrolündeki aşınma, taşınma ve birikmenin gelişimi değişir. Doğal kıyı, güncelliğini yitirmiş, geri dönüşü olmayacak şekilde eski kıyı (paleo kıyı) olmuştur. Morfodinamik sistem; yeni oluşturulan, güncel yapay kıyı koşulları ile etkinliğini sürdürür. Bu yüzden, kıyı ve morfodinamik sistemdeki değişimi ve değişime bağlı yeni jeomorfolojik özelliklerin esas alınması, tanımlanması, zaman içerisinde değişecek kıyı kullanımı ve planlamaların da bu yeni koşullara göre yapılması gerekmektedir. Bu gereklilik sadece bu çalışmada örneklenen yapay kıyılar için değil ayrıca Karadeniz sahil yolu yapay kıyıları, Yenikapı ve Maltepe yapay kıyıları, Ordu-Giresun Havalimanı dolgusuna ait yapay kıyılar ve diğer örnekler için de geçerlidir. Kıyıların doğal karakterlerinin, dolgu veya hafriyatlar ile değiştirilmemesi, morfodinamik etken ve süreçlere müdahale edilmemesi ve doğal sistemin sürdürülebilir kullanımının tercih edilmesi tabii ki temel prensip olmalıdır. Ancak bir şekilde ve sebeple gerçekleştirilen, doğal kıyı özelliklerinin tamamen ortadan kaldırılmasıyla oluşturulan, güncel yapay kıyılar için yukarıda özetlenen yaklaşımın esas alınarak; kıyı tanımlamasının ve bölümlerinin, elemanlarının belirlemelerinin yapılması, kıyı morfodimanik etken ve süreçlere ait tehlike ve risklerinin yeni yapay kıyı jeomorfolojisi için değerlendirilmesi ve planlamalarda hesaba katılması gerekmektedir. Zira bu hususun göz ardı edilmiş olduğu örneklerde; değişen dalga ve akıntı sistemlerinin etkinliği hesapta olmayan, çoğu kez istenmeyen kıyı erozyonlarına ya da kıyı birikimlerine, sığlaşma ve plaj oluşumlarına neden olmaktadır. Bu gereklilik; hem yapay kıyının sürdürülebilir kullanımının sağlanması, hem de doğal tehlike ve risklerine karşı doğal, ekonomik, sosyal zarar görebilirliğin engellenmesi, yapılan yatırımların ekonomik ömürlerini tamamlamadan atıl hale gelmemeleri için önemsenmelidir.

Jeomorfolojik özellikleri ve morfodinamik etken ve süreçlerin faaliyetleri dikkate alındığında; bu tür yapay kıyıların jenetik sınıflama içinde, "Dar-Yüksek Yapay Klyılar" ve "GenişAlçak Yapay Kıyılar" şeklinde iki alt sinıftan oluşan "Yapay Kıyllar" adı altında ayrı bir sinıf olarak kabul edilmesi de mümkün görülmekte ve önerilmektedir.

Kıyının yapay olması, yasal perspektifte özellikle mülkiyet açısından önemlidir. Yapay kıyılar; mülkiyet temelli problemlerle gündeme gelen, ilgili kanun ve yönetmelikler ile yasal prosedürleri olan hukuki bir konudur. Sulh Hukuk Mahkemelerinde devam etmekte olan konu ile ilgili çok sayıda dava olup, bu davaların bilirkişi heyeti tarafından yürütülen bilimsel değerlendirmelerinde, bu makale kapsamında özetlenmeye çalışılan yaklaşımın esas alınması önerilmektedir. Ayrıca 3621 sayılı Kıyı Kanunu ve bu kanunun Uygulanmasına Dair Yönetmeliklerde, yapay kıyıların bölümlerinin ve Kıyı Kenar Çizgilerinin yukarıda yapılan açıklamalar doğrultusunda tanımlanması ve jeomorfolojik yaklaşımlarla revize edilmesi önerilmektedir.

Diliskelesi kıyıları, yapay kıyılar ile ilgili tipik örnek bir saha olup, doğal kıyı özellikleri geri dönüşü olamayacak şekilde değiștirilmiștir. Jeomorfolojik olarak; İskele, derinsu batimetrisi, denizselliğin etkisinde olmayan dolgu alanı beton manevra platformu ile "Dar-Yüksek Yapay Kıyı" tipindedir.

Doğal kıyı üzerine dolgu yapılarak kazanılan alanın Sulh Hukuk Mahkemelerinde devam eden davaları genellikle mülkiyet ve kullanım problemi ile ilgilidir. Yapay kıyllardaki dolgu alanlarının "mülkiyet problemi” için yapay dolgu alanı sınırlarının yatay ve düşey doğrultularda jeomorfolojik esaslarla belirlenmesi ve sonuçların 3621 sayılı Kıyı Kanunu ve bu kanunun uygulanmasına dair yönetmelikler doğrultusunda değerlendirilmesi gerekmektedir. "Yapay kıyıların kullanım türü" hakkındaki problemlerin çözümünde ise güncel kıyı tipi (Dar Yüksek Kıyı ve Geniş-Alçak Kıyı) belirlemesi önemlidir. Bu kapsamda esas alınacak olan Karasal Kıyı Kenar Çizgisi; güncel 
yapay kıyı elemanları ve onların sınır özellikleridir. "Karasal Kıyı Kenar Çizgisi” güncel yapay kıyı tipine göre belirlenmeli ve Sahil şeridi, arazi kullanımı, yapılaşma vb. planlamaların 3621 sayılı Kiyı Kanunu ve bu kanunun uygulanmasina dair yönetmelikler doğrultusunda gerçekleştirilmesi gerekir.

Teşekkür: Makalede kullanılan sondaj ve batimetri verilerinin temin edilmesindeki katkıları nedeni ile Altıntel Liman ve Terminal İşletmeleri A.Ş. ye teşekkür ederim.

Finansal Destek: Yazar bu çalışma için finansal destek almamıştır.

\section{KAYNAKLAR}

Alcantara-Carrio, J., Fontán, B.A., Albarracin, S., Correa, I.D., Montoya, M.I. ve Mahiques, M. (2014). Geomorphological coastal classifications after natural processes and human disturbance. Journal of Oceanography and Marine Research, 2/3, 1-2. doi:10.4172/2332-2632.1000e108

Andrews, P. B. ve van der Lingen, G. J. (1969). Environmentally significant sedimentologic characteristics of beach sands, New Zealand Journal of Geology and Geophysics, 12(1), 119-137. doi: 10.1080/00288306.1969.10420230

Anthony, E. J. (1994). Natural and artificial shores of the French Riviera: an analysis of their interrelationship. Journal of Coastal Research, 10(1), 48-58. Erişim adresi: https://www.jstor.org/ stable/4298192?seq=1\#page_scan_tab_contents

Avcı, M. (2017). Türkiye'nin kıyı kumullarında bitki örtüsü. H. Turoğlu ve H. Yiğitbaşığlu (Ed.), Yasal ve bilimsel boyutlarıla KIYI (s. 63-92) içinde. Jeomorfoloji Derneği Yayınları, Yayın no: 1 , İstanbul.

Bird, E. (2008). Coastal geomorphology: An introduction_Second edition. John Wiley \& Sons Ltd, The Atrium, Southern Gate, Chichester, West Sussex PO19 8SQ, England.

Bradshaw, M. J., Abbott, A. J. ve Gelsthorpe, A. P. (1989). The Earth's changing surface. Hodder And Stoughton.

Davidson-Arnott, R. (2010). Introduction to coastal processes and geomorphology. Cambridge University Press. New York.

Edwards, A. C. (2001). Grain size and sorting in modern beach sands. Journal of Coastal Research, 17(1), 38-52. Erişim adresi: https:// www.jstor.org/stable/4300148?seq=1\#page_scan_tab_contents

Erginal, A.E. ve Öztürk, M. Z. (2010). Kızılırmak Deltası plaj sırtlarının taramal1 elektron mikroskobu analizleri ve tane boyu parametreleri ile incelenmesi. Türk Coğrafya Dergisi, 54, 41-50. Erişim adresi: https://dergipark.org.tr/download/article-file/198459

Erinç, S. (1971). Jeomorfoloji II. Genişletilmiş 2. Baskl. İ.Ü. Yayınları No: 1628, İ.Ü. Coğrafya Enstitüsü Yayınları No: 23, İstanbul.

Erinç, S. (1986). Kıyılardan yararlanmalarda hukuki düzenlemelere jeomorfolojinin katk1s1. Jeomorfoloji Dergisi, 14, 1-5. Ankara.
Erol, O. (1989). Türkiye'de kıyıların doğal niteliği, kıyının ve kıyı varlıklarının korunmasına ilişkin Kıyı Kanunu uygulamaları konusuna jeomorfolojik yaklaşım (A geomorphological approuch to the application of the laws for the coastal protection in Turkey). Ístanbul Üniversitesi Deniz Bilimleri ve Coğrafya Enstitüsü Bülten, 6, 15-47, İstanbul.

Erol, O. (1991). Türkiye kıyılarındaki terk edilmiş limanlar ve bir çevre sorunu olarak kıyı çizgisi değişimlerinin önemi. İ.Ü. Deniz Bilimleri ve Coğrafya Enstitüsü Bülteni, 8, 11-44.

Erol, O. (1996). Türkiye'deki kıyı kullanım sorunlarına jeomorfolojik yaklaşım. Türkiye Coğrafyası Araştırma ve Uygulama Merkezi III. Coğrafya Sempozyumu, s. 93-122. Erişim adresi: http://tucaum. ankara.edu.tr/wp-content/uploads/sites/280/2015/08/tucaum6_6.pdf

Fairbridge, R. W. (2004). Classification of coasts. Journal of Coastal Research, 20(1), 155 - 165. Erişim adresi: https://www.jcronline. org/doi/full/10.2112/1551-5036\%282004\%2920\%5B155\%3ACO $\mathrm{C} \% 5 \mathrm{D} 2.0 . \mathrm{CO} \% 3 \mathrm{~B} 2$

Friedman, G. M. (1961). Distinction between dune, beach, and river sands from their textural characteristics, Journal of Sedimentary Petrology, 31(4), 514-529. Erişim adresi: http://dx.doi.org/10.1306/ 74D70BCD-2B21-11D7-8648000102C1865D

Hudson, B. J. (1980). Antropogenic coasts. Geography, 65, 194-202. Erişim adresi: https://www.jstor.org/stable/pdf/40569272.pdf

Inman, D. L. ve Nordstrom, C. E. (1971). On the tectonic and morphologic classification of coasts. The Journal of Geology, 79 (1), 1-21. Erişim adresi: https://www.jstor.org/stable/30060828? seq=1\#metadata_info_tab_contents

Johnson, D. W. (1919). Shore processes and shoreline development. First Edition. John Wiley and Sons, New York.

Karunarathna, H., Horrillo-Caraballo, J., Ranasinghe, R., Short, A. ve Reeve, D. (2012). An analysis of cross-shore profile evolution of a sand and a composite sand-gravel beaches. Marine Geology, 299302, 33-42. doi: 10.1016/j.margeo.2011.12.011

Kayan, İ. (1997). Türkiye'nin Ege ve Akdeniz kıyılarında deniz seviyesi ve kıyı çizgisi değişmeleri. E. Özhan (Ed.) Türkiye'nin Kıyı ve Deniz Alanları 1. Ulusal Konferansı, Türkiye Kıyıları 97 Konferansı Bildiriler Kitabı (s. 735-746). Kıyı Alanları Yönetimi Türk Milli Komitesi (KAY) Orta Doğu Teknik Üniversitesi, Ankara.

Kobayashia, A., Udab, T. ve Noshia, Y. (2015). Shoreline devastation of Hota coast by man-made causes. Procedia Engineering, 116, 171 178. Erişim adresi: https://www.sciencedirect.com/science/article/ pii/S1877705815019347

Li, J., Yang, L., Pu, R. ve Liu, Y. (2017). A review on anthropogenic geomorphology. Journal of Geographical Sciences, 27 (1), 109128. doi: 10.1007/s11442-017-1367-7

Öner, E., Uncu, L. ve Hocaoğlu, B. (2002). Türkiye'nin doğu Akdeniz kıyılarında deniz seviyesi ve kıyı çizgisi değişmeleri. E. Özhan ve N. Alpaslan (Ed.) Türkiye'nin Kıyı ve Deniz alanları IV. Ulusal Konferansı, Türkiye Kıyıları 02 Konferans Bildirileri Kitabı (s. 1237-1247) içinde. Kıyı Alanları Yönetimi Türk Milli Komitesi (KAY) Orta Doğu Teknik Üniversitesi, Ankara. 
Pinet, P. R. (1996). Invitation to oceanography. West Publishing Company, St. Paul, MN. USA.

Shepard, F. P. (1963). Submarine geology, 2nd end. Harper and Row, New York.

Szabó, J. (2010). Anthropogenic geomorphology: Subject and System. J. Szabó, L. Dávid ve D. Lóczy (Ed.) Anthropogenic Geomorphology, A Guide to Man-Made Landforms (s. 3-13) içinde. Erişim adresi: https://www.researchgate.net/publication/272403864_ Anthropogenic_Geomorphology

Turoğlu, H. (2009). 3621 sayılı kıyı kanunu ve onun uygulama problemleri (The Coastal Law (number 3621) and Its Applied Problems). Türk Coğrafya Dergisi, 53, 31-40, İstanbul. Erişim adresi: https://dergipark.org.tr/download/article-file/198464

Turoğlu, H. (2010). Alçak kıyılarda kıyı kenar çizgisi problemi. Ulusal Jeomorfoloji Sempozyumu 2010, Bildiriler Kitabı. 206-218, Afyon. Erişim adresi: http://ujes.org/wp-content/uploads/2016/12/UlusalJeomorfoloji-Sempozyumu-2010-Afyon.pdf

Turoğlu, H. (2017a). Deniz ve göllerde kıyı. H. Turoğlu ve H. Yiğitbaşıŏlu (Ed.), Yasal ve Bilimsel Boyutlarlyla KIYI. (s. 01-32) içinde. Jeomorfoloji Derneği Yayınları, Yayın no: 1, İstanbul.
Turoğlu, H. (2017b). Kıyı mevzuatı ve jeomorfolojik değerlendirmesi. H. Turoğlu ve H. Yiğitbaşığlu (Ed.), Yasal ve Bilimsel Boyutlarıyla KIYI (s. 51-68) içinde. Jeomorfoloji Derneği Yayınları, Yayın no: 1, İstanbul.

Turoğlu, H. (2019). Jeomorfolojik ve yasal perspektifte yapay kıyılar (Artificial Coasts From The Geomorphological And Legal Perspective). H. Sözbilir, Ç. Özkaymak, B. Uzel, Ö. Sümer, M. Softa, Ç. Tepe ve S. Eski (Ed.), Uluslararası Katılımlı 72. Türkiye Jeoloji Kurultayı Bildiriler kitabı (72nd Geological Congress of Turkey with international participation, Proceedings)(s. 271-272) içinde. TMMOB Jeoloji Mühendisleri Odası Yayınları No: 140. Erişim adresi: https://www.jmo.org.tr/resimler/ekler/174e0f6fa731 893 ek.pdf

Yiğitbaşığlu, H. (2017). Kıyı dinamikleri ve süreçler. H. Turoğlu ve H. Yiğitbaşığlu (Ed.) Yasal ve Bilimsel Boyutlartyla KIYI (s. 31-44) içinde. Jeomorfoloji Derneği Yayınları, Yayın no: 1, İstanbul. 
